\title{
Sedimentary and tectonic setting of a mass-transport slope deposit in the Halifax Group, Halifax Peninsula, Nova Scotia, Canada
}

\author{
JOHN W.F. WALDRON ${ }^{1 *}$, REBECCA A. JAMIESON ${ }^{2}$, HAYLEY D. POTHIER ${ }^{1,3}$, AND CHRIS E. WHITE ${ }^{4}$
}

1. Department of Earth \& Atmospheric Sciences, 1-26 Earth Science Building, University of Alberta, Edmonton Alberta T6G2E3, Canada 2. Department of Earth Sciences, Dalhousie University, Halifax, Nova Scotia B3H 4R2, Canada

3. Current address: Dassuault Systèmes GEOVIA Inc., 110 Yonge Street, Suite 1400, Toronto, Ontario M5C 1T4

4. Nova Scotia Department of Natural Resources, Halifax, Nova Scotia B3J 2T9, Canada

*Corresponding author $<$ john.waldron@ualberta.ca $>$

Date received: 04 October 2014 Date accepted: 11 January 2015

\begin{abstract}
Fine-grained metasedimentary rocks of the Halifax Group in southern mainland Nova Scotia can be subdivided into mappable units. In Halifax Peninsula, sulphide-rich hornfels, black slate, metasiltstone, and metasandstone of the Cunard Formation are overlain by grey metasedimentary rocks with abundant cross-laminations and local carbonate and calc-silicate concretions, assigned to the Bluestone Quarry Formation. No fossils are known from the Bluestone Quarry Formation but lithological correlatives elsewhere are Tremadocian. The Bluestone Quarry Formation is here divided into four members. The lowest (Point Pleasant member) contains thin parallel-laminated and cross-laminated metasandstone beds with Bouma $\mathrm{T}_{\text {bcde }}$ and $\mathrm{T}_{\text {cde }}$ structures, and thicker beds with Bouma 'a' divisions. The Black Rock Beach member lacks the thicker massive beds and is dominated by rippled and cross-laminated metasedimentary rocks. The overlying Chain Rock member, an erosion-resistant ridge-forming unit, is disrupted by folds and boudinage. Bedding is truncated at the upper contact, and the internal structures are overprinted by (and therefore predate) the Neoacadian cleavage. They are interpreted as products of synsedimentary mass transport. Scarce folds in the Chain Rock member and current ripples in the underlying unit are consistent with a N or NW transport direction. The overlying Quarry Pond member consists of thinly bedded coherent metasedimentary rocks that generally resemble those of the Black Rock Beach member. Although there are indications of upward shallowing in equivalent successions elsewhere in the Halifax Group, the presence of a major mass transport deposit in the Bluestone Quarry Formation shows that this part of the Halifax Group was deposited on a submarine paleoslope. The failure of geologists to identify this feature in much-visited outcrops testifies to the difficulty of identifying synsedimentary deformation features that have been overprinted by later tectonic deformation.
\end{abstract}

\section{RÉSUMÉ}

Les roches métasédimentaires à grains fins du groupe d'Halifax situées dans la région méridionale de la partie continentale de la Nouvelle-Écosse peuvent être divisées en unités cartographiables. Dans la péninsule d'Halifax, les cornéennes riches en sulfures, l’ardoise noire, la métasiltite et le métagrès de la formation de Cunard sont recouverts de roches métasédimentaires grises ainsi que d'une abondance de stratifications entrecroisées et de foyers de concrétions de carbonate et de silicate calcique attribués à la formation de Bluestone Quarry. Aucun fossile nesst associé à la formation de Bluestone Quarry, mais les corrélations lithologiques établies ailleurs sont du Trémadocien. La formation de Bluestone Quarry est ici divisée en quatre membres. Le premier, soit le membre de Point Pleasant, contient de minces lits de métagrès à stratification parallèle et entrecroisée, des structures de niveau $\mathrm{T}_{\text {cde }}$ et $\mathrm{T}_{\text {bcde }}$ selon la séquence de Bouma ainsi que des lits plus épais présentant des couches « a " selon la séquence de Bouma. Le membre de Black Rock Beach ne présente pas ces lits massifs et épais et contient principalement des métasédiments ondulés et à stratification entrecroisée. Le membre de Chain Rock sus-jacent, une unité résistante à lérosion et formant des crêtes, est interrompu par des plis et des boudinages. Le litage est tronqué à la zone de contact supérieur et les structures internes sont recoupées par le clivage néo-acadien (elles sont donc plus anciennes). Elles sont considérées comme des produits du transport en masse synsédimentaire. Les rares plis observés dans le membre de Chain Rock et les ondulations présentes dans l'unité sous-jacente semblent indiquer que le transport se serait effectué en direction nord 
ou nord-ouest. Le membre de Quarry Pond sus-jacent est composé de roches métasédimentaires cohérentes finement litées qui ressemblent généralement à celles du membre de Black Rock Beach. Il y a des indications de diminution de la profondeur dans des successions équivalentes observées ailleurs dans le groupe d'Halifax, mais la présence d'un important dépôt de transport en masse dans la formation de Bluestone Quarry indique que cette partie du groupe d'Halifax a été déposée sur un paléotalus sous-marin. Les géologues ne sont pas arrivés à cerner cette caractéristique dans des affleurements souvent visités, ce qui témoigne de la difficulté à observer les déformations synsédimentaires surmontées d'une déformation tectonique subséquente.

[Traduit par la redaction]

\section{INTRODUCTION}

Debris flows and other types of mass-transport deposit (MTD), including slump and slide sheets, cover significant areas of modern deep-marine clastic environments (e.g., Schwab et al. 1996; Ducassou et al. 2013), suggesting that they should be common in ancient turbidite successions. Although spectacular ancient MTDs are well known in some ancient deepwater successions (e.g., Arnott et al. 2011; Gagnon and Waldron 2011), identified MTDs are scarce or absent in descriptions of many other ancient turbidite deposits, including those of the early Paleozoic Meguma terrane of Nova Scotia. Part of this discrepancy may reflect failure to recognize MTDs in ancient successions, where they may be missed because of the lack of associated fabrics (e.g., Debacker et al. 2001) or confused with products of tectonic deformation (e.g., Waldron and Gagnon 2011). In this paper we describe a unit of deformed metaclastic rocks in the Halifax Group, in the Meguma terrane, which has the classic characteristics of a MTD. The unit, the Chain Rock member of the Bluestone Quarry Formation, is exposed on the Halifax Peninsula within walking distance of several university campuses, and has been visited over many decades by generations of geology students and their instructors (including all the present authors), but has not been characterized or understood before this study.

The Meguma terrane of the Canadian Appalachians (Fig. 1 ) is confined to Nova Scotia and adjacent offshore areas, and is characterized by a thick succession of Cambrian to Ordovician metaclastic rocks. A lower metasandstonedominated succession of Cambrian age, the Goldenville Group, interpreted mainly as turbidites (e.g., Phinney 1961; Schenk 1970), is overlain by the finer-grained Halifax Group, of Furongian (late Cambrian) to Early Ordovician age (White et al. 2012). Although lower parts of the Halifax Group have been interpreted as turbidites (Stow et al. 1984), higher units in the Wolfville area show increasing bioturbation (White et al. 2012) and have been interpreted to represent outer shelf or prodelta environments.

Both the Halifax Group and the underlying Goldenville Group were deformed into upright to steeply inclined folds with pervasive axial planar cleavage during the Neoacadian

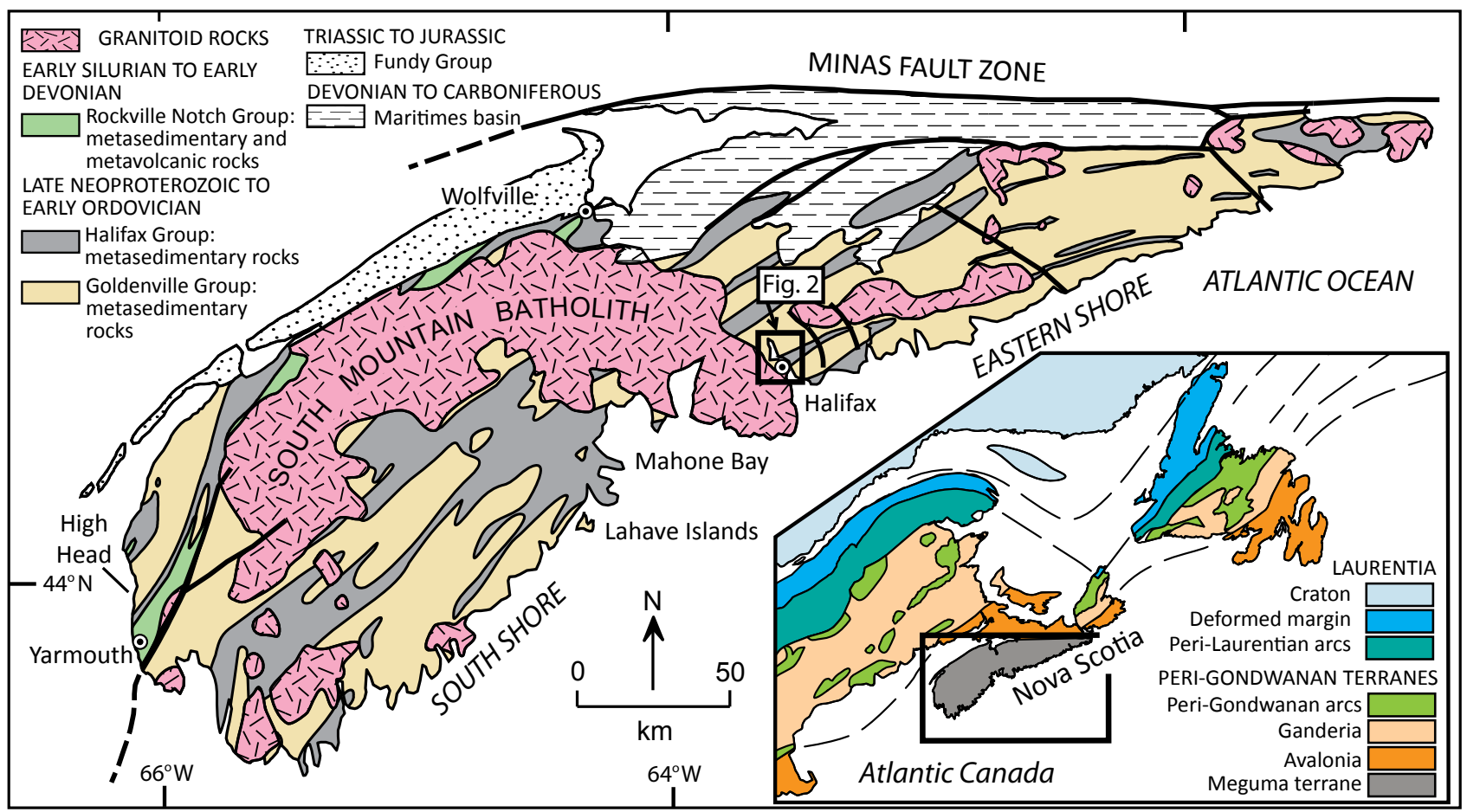

Figure 1. Map of the Meguma terrane in southern mainland Nova Scotia, showing the location of the study area. Inset: regional map of Northern Appalachian orogen after Hibbard et al. (2006). 
orogeny (Reynolds et al. 1973; Culshaw and Liesa 1997; Culshaw and Reynolds 1997). This deformation was followed by intrusion of the South Mountain Batholith and related plutons in the Middle to Late Devonian. Subsequent tightening of the folds (Horne and Culshaw 2001) may have been associated with movement on the Minas Fault Zone (Murphy et al. 2011) and related later Paleozoic strikeslip faults. Thus most of the structures seen in the Halifax Group have been interpreted as of tectonic origin.

\section{STRATIGRAPHY OF HALIFAX PENINSULA}

Cambrian-Ordovician metasedimentary rocks of southern mainland Nova Scotia are assigned to two groups - the lower Goldenville Group, dominated by metasandstone, and the upper Halifax Group, dominated by metapelite. Classic exposures of the Halifax Group occur in Halifax Peninsula (Fig. 2) and surrounding areas, where they have been visited by generations of university students. Despite the metamorphism and deformation, sedimentary structures can clearly be recognized in both groups. However, the succession (originally mapped as Halifax Formation) was not subdivided by Faribault (1908). Recent mapping by White et al. (2008) has shown that it is possible to identify four formations on Halifax Peninsula. Of these, the Bluestone Quarry Formation is formally defined in a companion publication by Pothier et al. (2015); the others remain informal and were designated with lowercase "formation" by White (2010). However, in accordance with current journal policy they are shown in uppercase here and in the companion paper.

\section{Taylors Head Formation}

The Taylors Head Formation represents the top of the "typical" Goldenville Group. It consists of dominantly medium- to thick-bedded $(10 \mathrm{~cm}$ to $1 \mathrm{~m})$ relatively quartzrich metawacke, interbedded with thinner intervals of slate. Sedimentary structures include grading, which is typically weak and confined to the top few centimetres of the thicker beds, and also sole markings that include spectacular groove casts and less common flutes. Thicker beds display internal scour-and-fill structures superficially resembling hummocky cross-stratification. However, Waldron and Jensen (1985), working on stratigraphically equivalent rocks in eastern Nova Scotia, showed that even these have a unidirectional character; they are likely incipient dunes formed in high-concentration sediment gravity flows, similar to those described by Sylvester and Lowe (2004) and Sumner et al. (2012).

\section{Beaverbank Formation}

Overlying grey-green, locally manganiferous mudrock is assigned to the Beaverbank Formation. Laterally equivalent muddy units are widespread in the Goldenville-Halifax transition (Waldron 1991). Though historically assigned to the Halifax Group, these rocks are included in the uppermost Goldenville Group in recent mapping (e.g., White 2010).

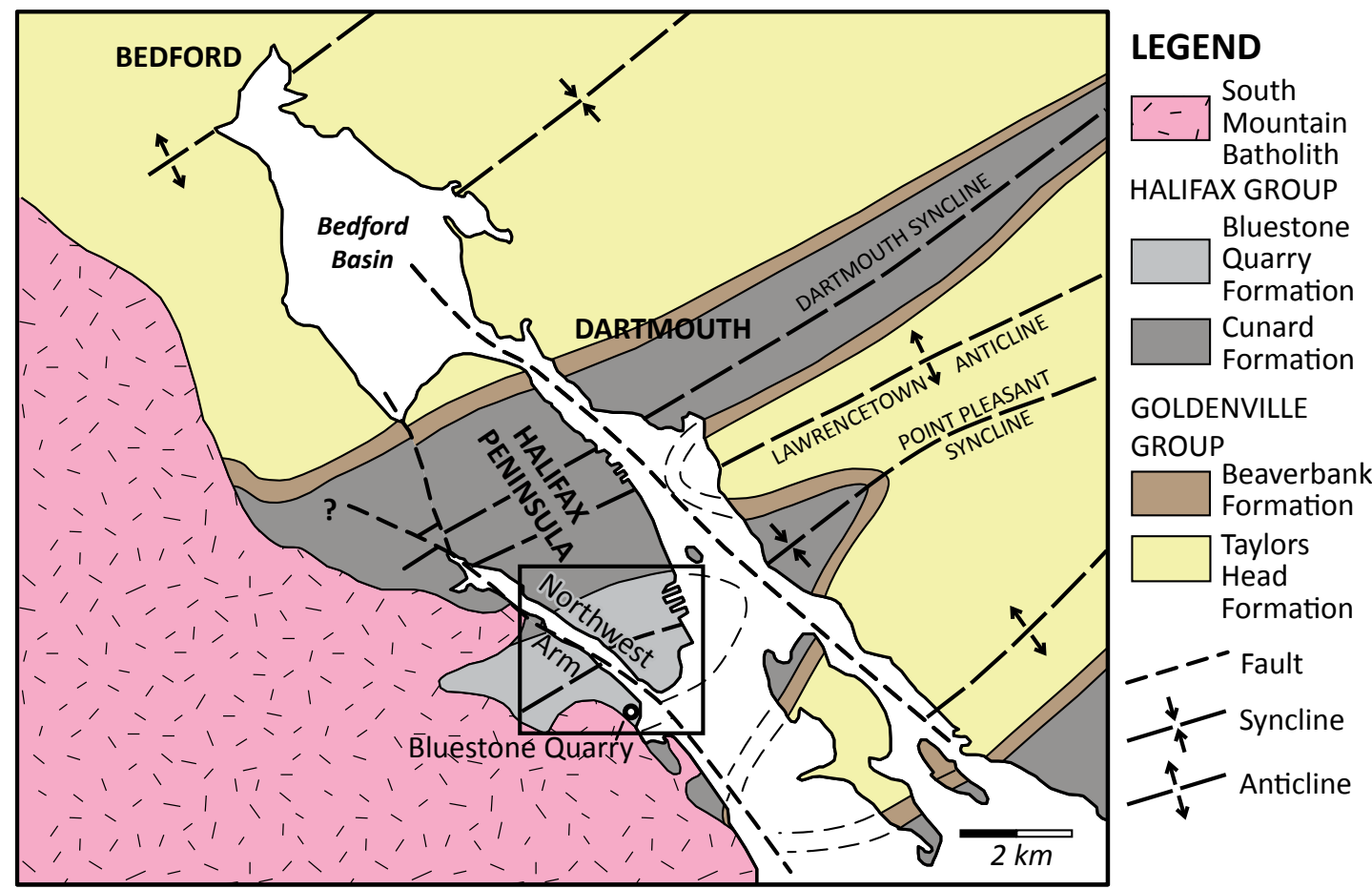

Figure 2. Map of Halifax Peninsula and adjoining areas after White et al. (2008) and White and Goodwin (2011). Box encloses area of Fig. 8. 


\section{Cunard Formation}

Black, pyrrhotite- and pyrite-rich slate and metasiltstone of the Cunard Formation are the most areally extensive rocks on Halifax Peninsula, and are widely regarded as the most "typical" facies of the Halifax Group. When freshly exposed to weathering during construction and quarrying, these rocks, because of their high concentration of sulphides, particularly pyrrhotite, are responsible for acid drainage which has been a significant environmental concern in many areas of southern mainland Nova Scotia (White and Goodwin 2011).

\section{Bluestone Quarry Formation}

The Bluestone Quarry Formation (Jamieson et al. 2005; White 2010; Pothier et al. 2015) is the main focus of this paper. It forms the stratigraphically highest pre-Quaternary unit on Halifax Peninsula. It is paler, more varied in colour, and slightly coarser than the underlying Cunard Formation. Spectacular cross-lamination is displayed in many coastal exposures, notably in Point Pleasant Park at the south end of Halifax Peninsula (Fig. 2). It is also characterized by sporadic carbonate concretions, which occur preferentially in certain beds, presumably controlled by porosity or permeability variations during early diagenesis. Within the aureole of the South Mountain Batholith, these concretions are mostly metamorphosed to an assemblage of calcsilicate minerals documented by Jamieson et al. (2012). Because of their different bulk compositions, the Cunard and Bluestone Quarry formations respond differently to thermal metamorphism. Jamieson et al. (2012) showed that in the Cunard Formation andalusite appears at lower metamorphic grade than biotite, whereas in the Bluestone Quarry Formation the reverse is the case. The sharp offset in the andalusite-in isograd assists mapping the stratigraphic contact within the metamorphic aureole.

Within the Bluestone Quarry Formation, we are able to recognize four distinct members, mappable in the south end of peninsular Halifax and adjacent areas west of Northwest Arm.

\section{Point Pleasant member}

A lower unit, approximately $295 \mathrm{~m}$ thick, contains slates that are interbedded with sporadic medium- to thickbedded graded sandstone layers (Figs. 3a, b, 4) that show Bouma (1962) $\mathrm{T}_{\text {abcde }}$ and $\mathrm{T}_{\mathrm{ae}}$ sequences of sedimentary structures indicative of high-energy turbidite flows. This unit is well seen in coastal and inland exposures in the southern half of Point Pleasant Park and is here designated the Point Pleasant member. Figure 4 shows typical sections in which sandstone beds range up to $\sim 40 \mathrm{~cm}$ in thickness. However, on the western shore of the Northwest Arm (Fig. 2) the Point Pleasant member also contains at least two laterally continuous, coarse-grained, quartz-rich sandstone beds up to $1 \mathrm{~m}$ thick. Cross-lamination is common in crosssection views and typically shows a strong component of paleoflow to the NW. However, only rare exposures of the top surfaces of sandstone and siltstone beds show straightcrested ripples in plan view with sufficient preservation (Fig. 3c) for quantitative measurement of paleoflow. Basal surfaces of beds are almost never exposed, and we were unable to locate measureable flutes or grooves. Accordingly, we merge ripple data from the two lower members of the Bluestone Quarry Formation in Figure 5. Most measured ripple crests are approximately parallel to the WSW strike of the beds, while cross-sections of ripple foresets show a component of flow to the NW. However, because the rocks have been modified by tectonic strain, the measured crests of ripples have almost certainly been rotated towards the long axis of the bedding-plane strain ellipse, creating a more tightly clustered distribution; removal of tectonic strain provides a better picture of the scatter of paleocurrents (e.g., Waldron and Jensen 1985; Waldron 1988; Gingras et al. 2011). Unfortunately the Bluestone Quarry Formation contains no obvious strain markers, unlike the Goldenville Group, where sedimentary structures and trace fossils were used by these authors to measure strain. A bedding-plane strain ratio of 2.0 was assumed, with a shortening direction perpendicular to cleavage, based on the general similarity in deformation state to rocks on the Eastern Shore of Nova Scotia studied by Waldron and Jensen (1985). Orientations of ripple crests were restored to horizontal by rotation about the strike, followed by removal of this assumed distortion. Even after strain removal, the distribution (Fig. 5b) is still tightly clustered, with an average paleoflow towards $321^{\circ}$ (+/- $6.5^{\circ}, 95 \%$ confidence limits). The limitations of outcrop must be borne in mind when using these data to interpret paleoslope, as it is common for ripples in turbidite successions to record directions that differ from the local slope (e.g., Clayton 1993). Nonetheless, observations elsewhere in the Goldenville and Halifax groups show a general concordance of paleocurrents inferred from ripples and flutes, once the effects of tectonic strain are removed (Waldron 1988).

\section{Black Rock Beach member}

The overlying Black Rock Beach member is well known to generations of geology students who have been introduced to field geology at Black Rock Beach because of its convenient access and proximity to universities. The member is approximately $68 \mathrm{~m}$ thick. It is thinner bedded than the Point Pleasant member (beds $1-20 \mathrm{~cm}$ thick) and is dominated by sandstone and siltstone beds that are laminated and cross-laminated throughout (Bouma $\mathrm{T}_{\mathrm{bcde}}$ and $\mathrm{T}_{\text {cde }}$ sequences). Excellent sections occur on both shores of Point Pleasant Park (Fig. 6) and in the lower Bluestone Quarry west of the Northwest Arm. Despite the increasing degree of metamorphic recrystallization from east to west, primary sedimentary structures are clearly visible at all 

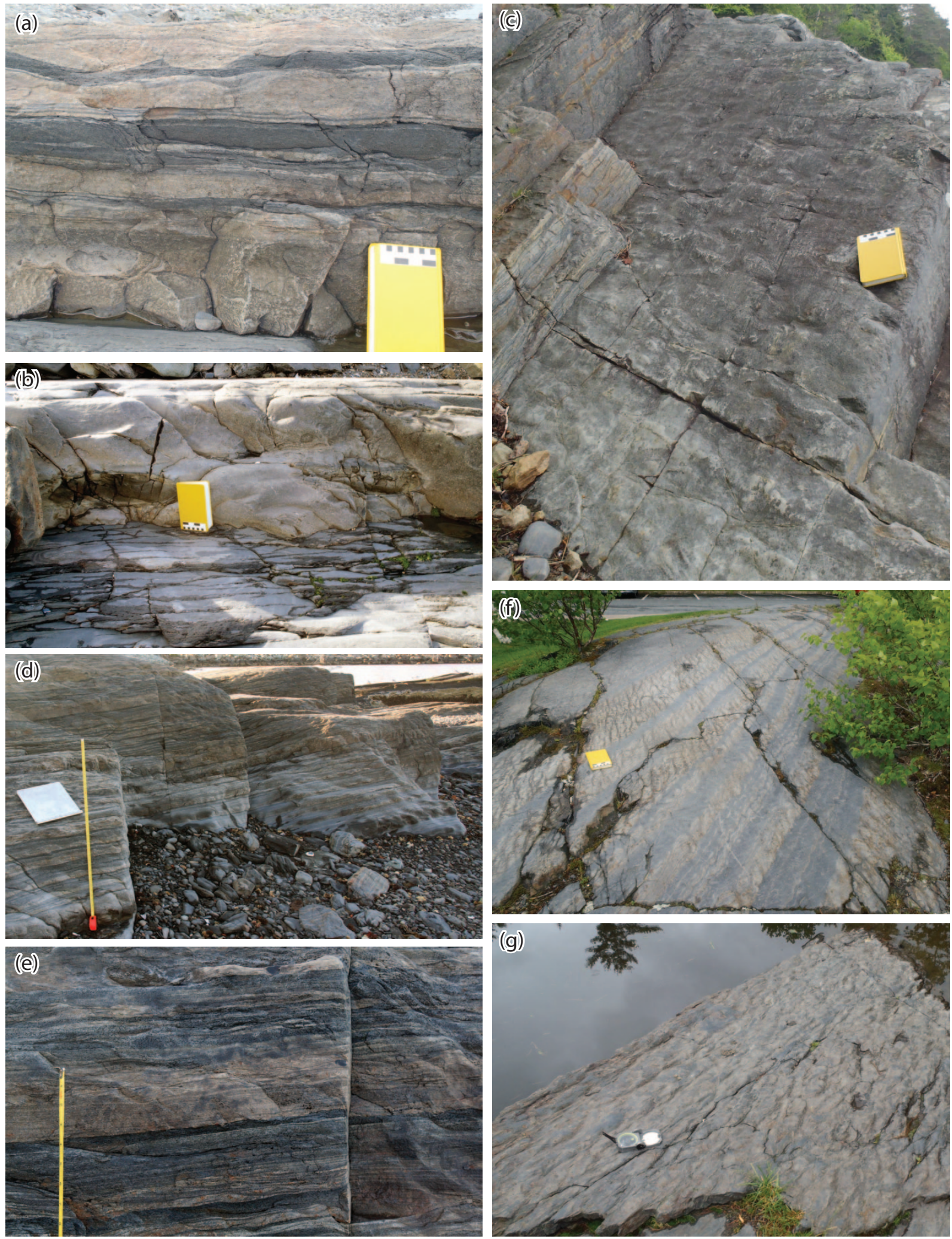

Figure 3. Field photographs of stratified units of the Bluestone Quarry Formation. (a) Typical outcrop of the Point Pleasant member, showing graded bedding and scoured basal surfaces. (b) Typical outcrop of the Point Pleasant member showing carbonate concretion (left of notebook). (c) Ripple marks on upper bedding surface of sandstone, Point Pleasant member. (d) Typical outcrop of the Black Rock Beach member, Black Rock Beach. (e) Close-up of Black Rock Beach member. (f) Typical outcrop of the Quarry Pond member, Ogilvie Tower. (g) Linguoid ripples distorted by tectonic strain, Quarry Pond member at Quarry Pond. 


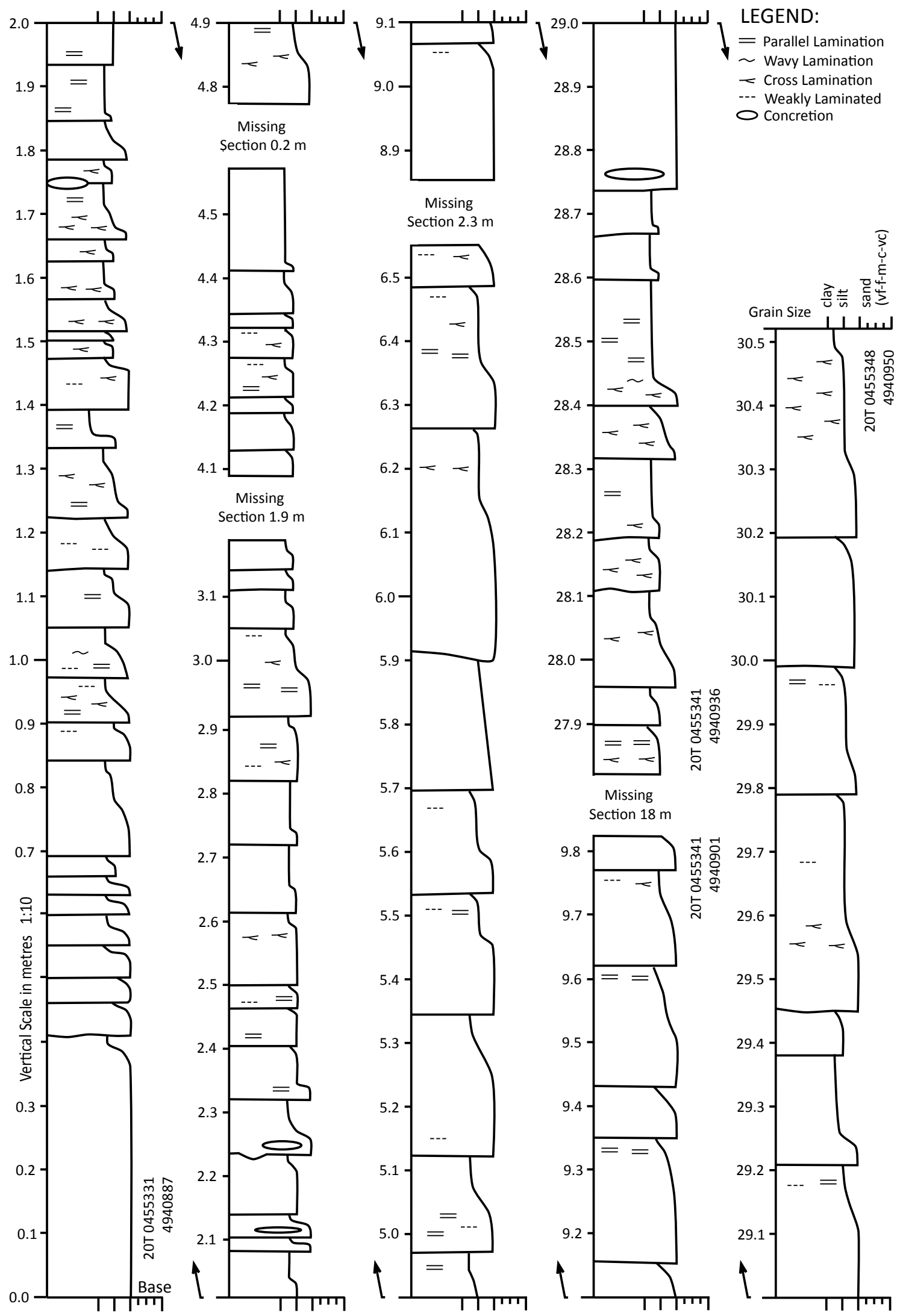

Figure 4. Detailed sections in the Bluestone Quarry Formation, Point Pleasant member. 
(a)

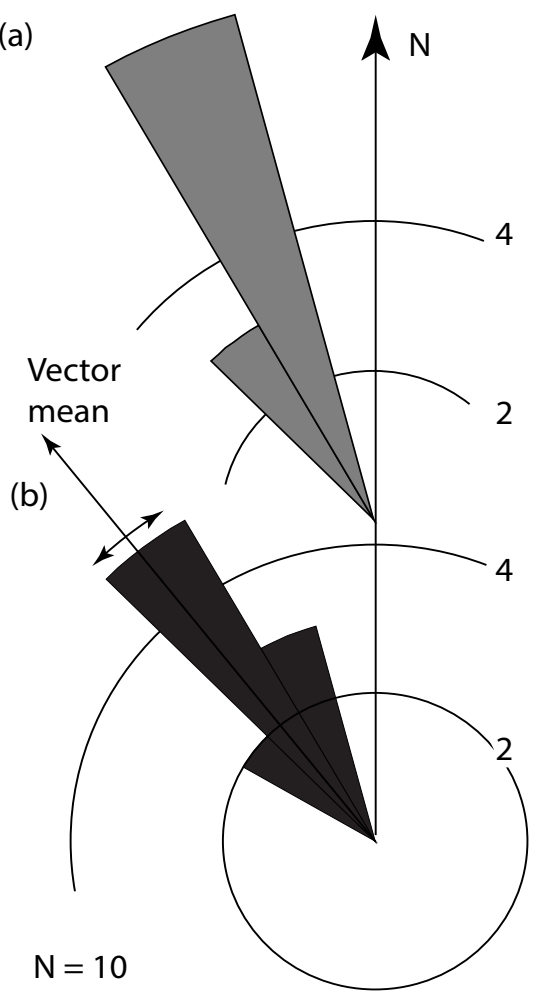

Figure 5. Paleocurrent rose diagrams derived from measurements of ripples in the Point Pleasant and Black Rock Beach members. (a) rotated to horizontal about strike. (b) same data restored by removal of estimated tectonic strain (strain ratio 2.0 ).

localities. Current-generated cross-lamination is again common (Figs. 3d, e), and indicates dominant paleoflow to the north or northwest. A single bedding surface exposed straight-crested ripples that were sufficiently well preserved to provide a paleocurrent direction estimate. The measured direction is not significantly different from those in the Point Pleasant member; data from both units are merged in Figure 5.

\section{Chain Rock member}

The Chain Rock member is a distinctive unit, about $75 \mathrm{~m}$ 0thick, with bedding that varies from discontinuous to folded to completely disrupted (Fig. 7). Within the northdipping succession in Point Pleasant Park, the member is more erosion-resistant than those above and below, probably because of the lack of frost-wedging along parallel parting surfaces. The unit forms a conspicuous ridge that was exploited for military fortifications in the 19th century (Fig. 8). However, north of the Point Pleasant Syncline, south-dipping strata of the Chain Rock member do not show a similar topographic feature, perhaps because erosion of south-dipping strata during Quaternary glaciation was mainly by mechanical erosion beneath south-flowing ice.

The most accessible and continuous exposure of the Chain Rock member is at the type locality, Chain Rock, on the NE shore of Northwest Arm. Although early deformation structures are conspicuous in this outcrop (Figs. 7a, b), their significance had not been realized due to the strong metamorphic overprint of the Halifax Pluton, which lies only $\sim 1 \mathrm{~km}$ away on the SW side of the Arm. The member here consists of massive hornfels, in which the cleavage has been largely annealed, and originally finergrained pelitic units display strongly pitted surfaces due to weathering of coarse retrogressed cordierite porphyroblasts. A similar range of features is observed at the western limit of exposure in the Bluestone Quarry; these outcrops also display excellent exposures of the basal contact of the unit (described further below).

Scattered outcrops occur along strike to the NE at inland locations within Point Pleasant Park, including abundant glacially polished surfaces around fortifications (Martello Tower and Fort Ogilvie; Fig. 7d). The member does not crop out on the east coast of the Peninsula. However, cores drilled in construction of Pier C (Fig. 8) recovered sections that showed steeply dipping and folded bedding (Fig. 7g), suggesting part of the member continues beneath Halifax Harbour. The member crosses the axial trace of the Point Pleasant syncline before reaching the coast, and strikes NW thereafter. Two complete but less accessible sections of the member occur in the railway cutting that crosses the Peninsula; both sections are partially overgrown with trees and bushes. At the east end of the cutting, continuous but overgrown outcrop, including both the lower and upper contacts, occurs near large grain elevators on the eastern side of the Peninsula (Fig. 7f). Traced west, the member passes through the campus of Saint Mary's University, where exposure of the upper contact occurs immediately south of the Sobey Building. Farther west still, the member again crosses the railway cutting, though this western section is less well exposed, and the contacts are difficult to locate in mud-rich lithologies. However, bedding and intersection-lineation orientations clearly indicate a component of deformation that pre-dates the regional folding and cleavage development. The unit is interpreted below as a product of downslope mass transport.

\section{Quarry Pond member}

The Quarry Pond member is named for exposures around Quarry Pond, a small flooded quarry close to the axial trace of the Point Pleasant syncline (Fig. 8). It shows a return to thinly bedded laminated and crosslaminated facies similar to those seen in the Black Rock Beach member (Fig. 3f). Distinct packages of beds show upward coarsening and thickening trends. Ripple crosslamination is abundant. However, the majority of ripples appear to have been linguoid in plan view, in contrast to the lower parts of the Bluestone Quarry Formation, where straight-crested ripples are common. The linguoid ripple shapes are heavily modified by strain; judging the original line of symmetry to estimate paleocurrent orientations is 
Figure 6. Detailed sections in the Bluestone Quarry Formation, Black Rock Beach member, at its western and eastern coastal intersections.

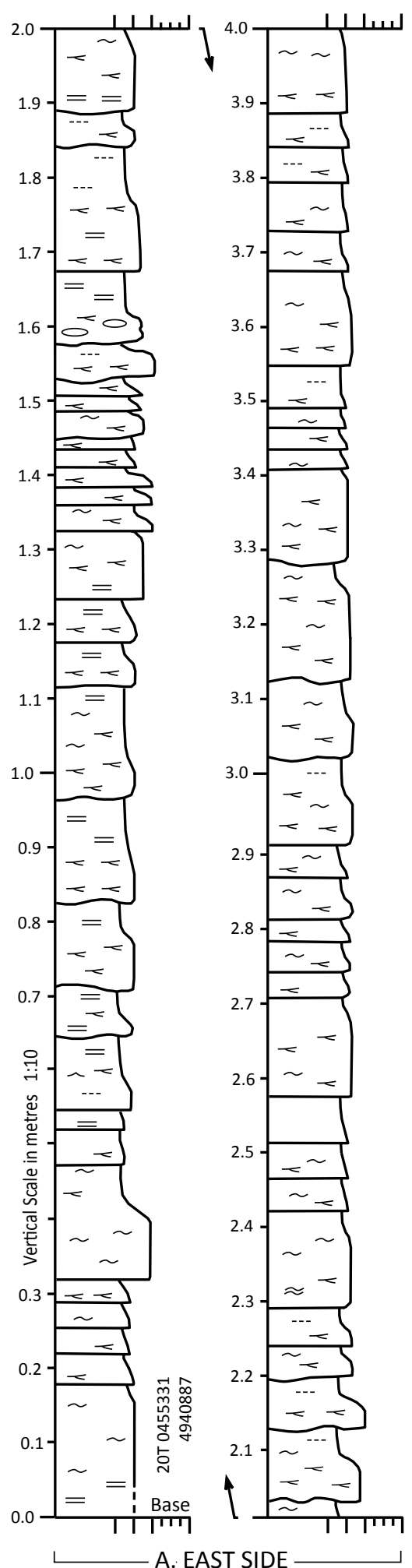

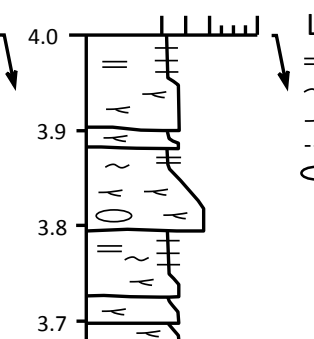

LEGEND:

$=$ Parallel Lamination

Wavy Lamination

- Cross Lamination

--- Weakly Laminated

Concretion

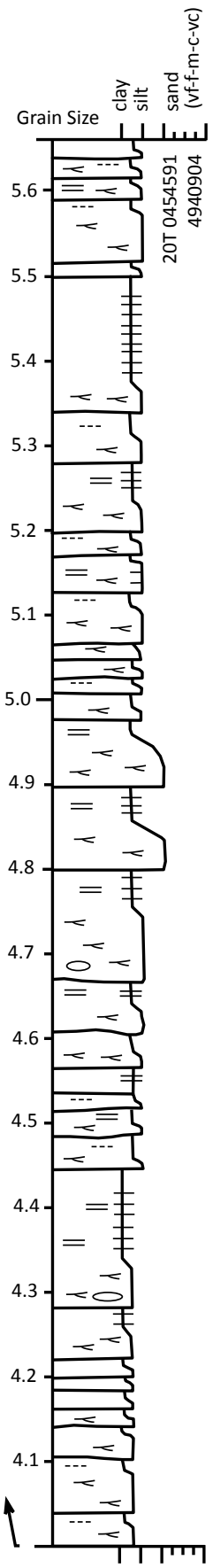

B. WEST SIDE
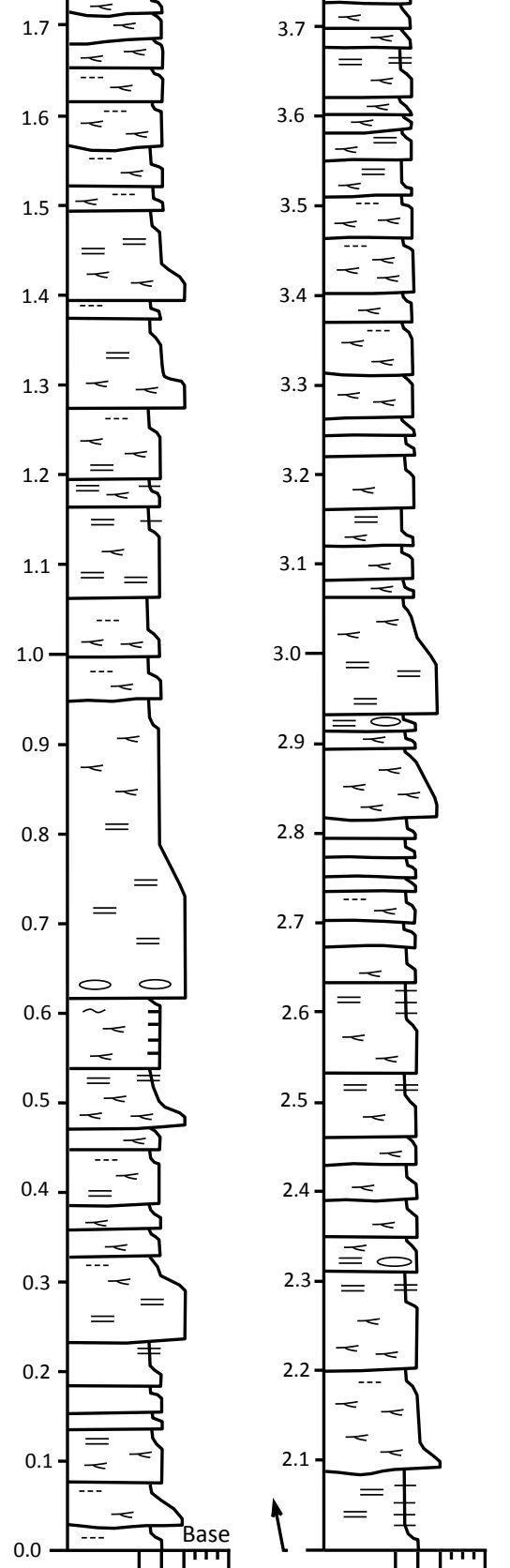

Figure 7 adjacent page (right). Field photographs of internal structure of Chain Rock member. (a) Isolated folded siltstone clast immersed in homogeneous hornfels, Chain Rock. Clipboard $22 \mathrm{~cm}$. (b) Hornfels at Chain Rock: folded bedding raft. (c) Bed fragments (arrows) forming rafts in homogeneous hornfels, Bluestone Quarry. (d) Isolated siltstone clasts preferentially weathering in outcrop with historic graffiti, Fort Ogilvie. (e) Plunging, downward facing folds in bedded siltstone raft, 200 $m$ east of Chain Rock. (f) Folded bedding producing curved intersection lineation on cleavage surface, railway cutting. (g) Core from $\sim 7 \mathrm{~m}$ depth, Pier C borehole BH107, showing steeply dipping folded beds. 

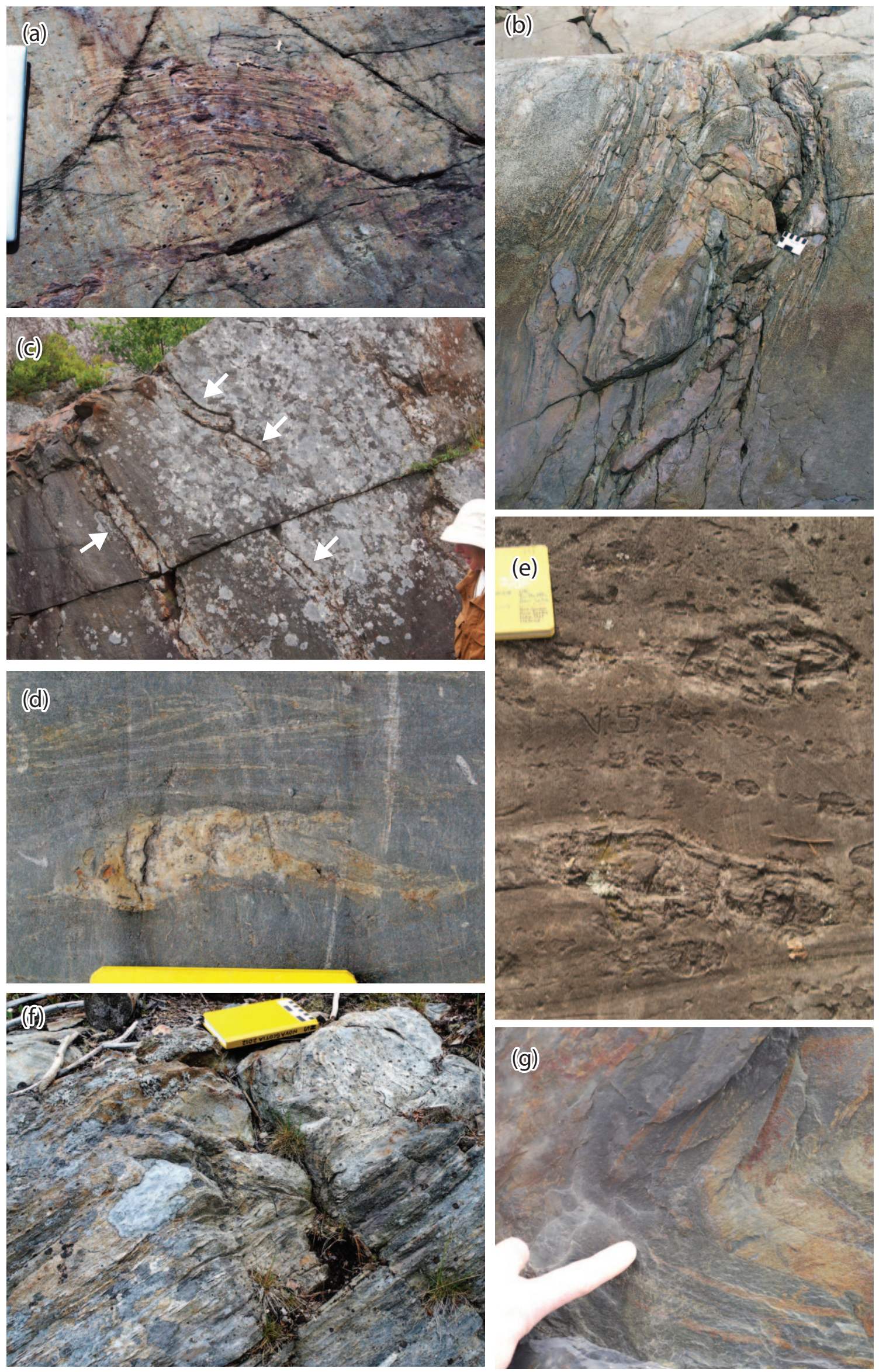
a

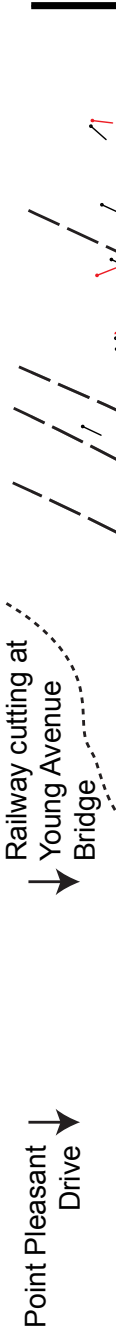

Figure 8. Cross section (a) and map (b) of Point Pleasant Park and surrounding areas. Map is superimposed on LiDAR bare-earth filtered image. Cross-section is projected from geologic map parallel to mean fold axis trend $252^{\circ}$ plunge $09^{\circ}$ onto a vertical plane with strike $162^{\circ}$. "Tadpoles" show projected apparent dip of bedding (black) and cleavage (red) on plane of section.

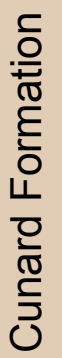

$\frac{0}{\frac{0}{0}}$
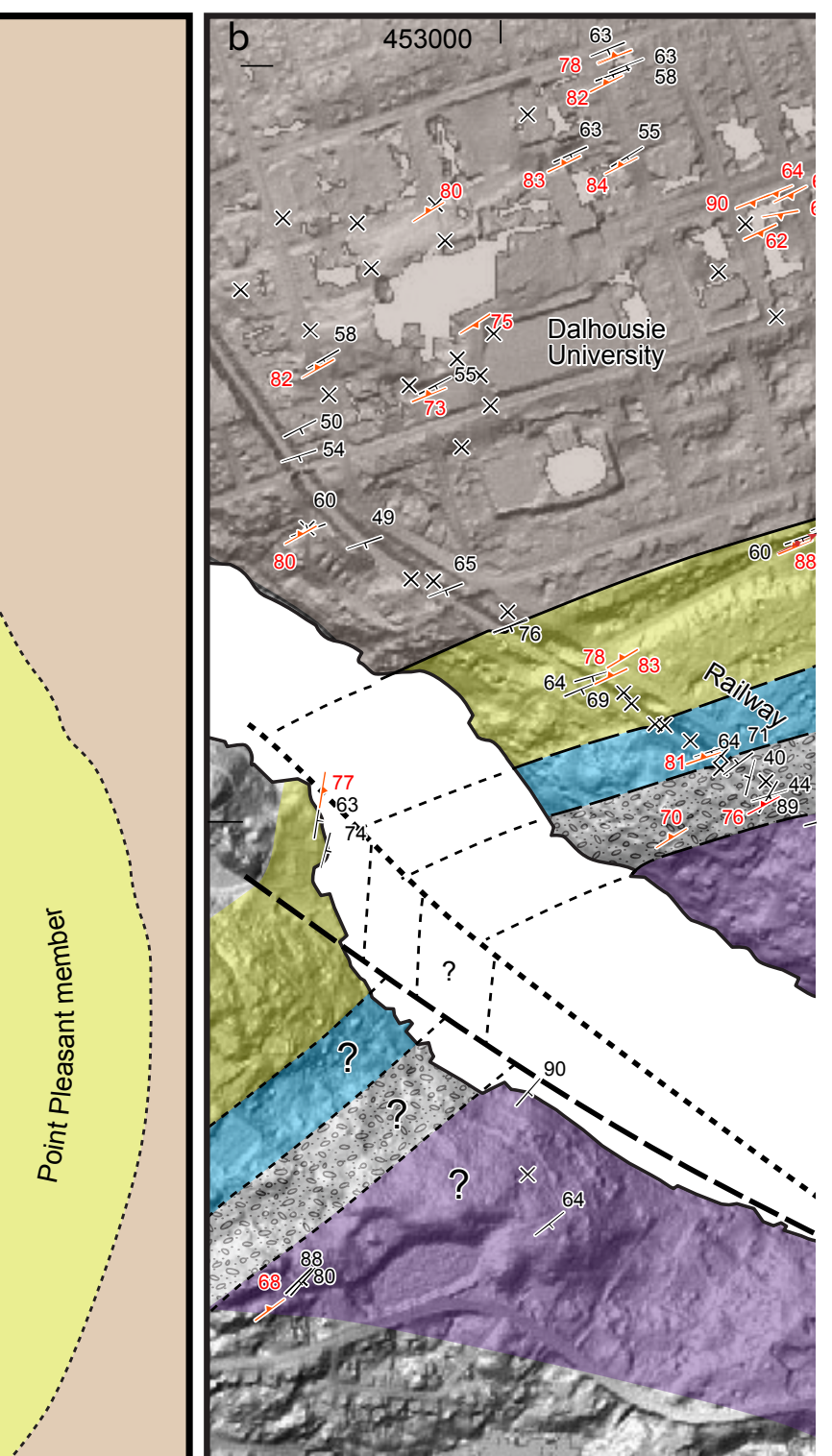

BLUESTONE QUARRY FORMATION
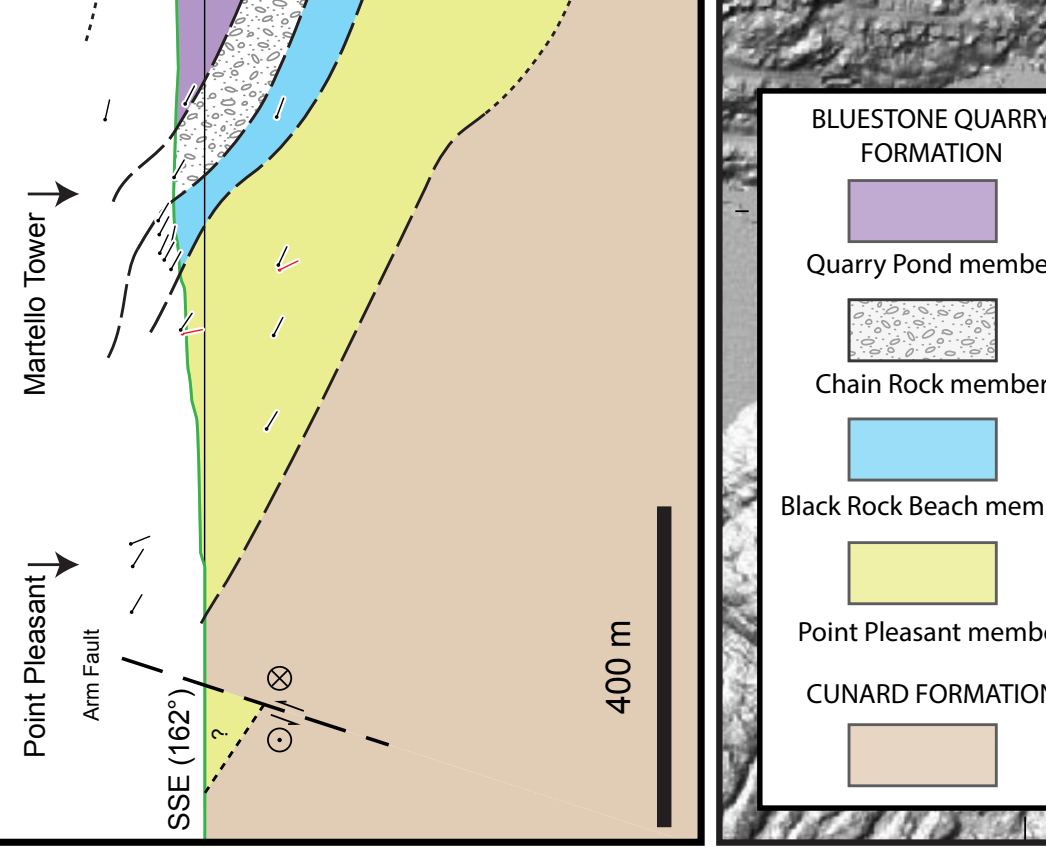

Chain Rock member

Black Rock Beach member

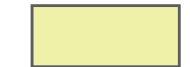

Point Pleasant member

CUNARD FORMATION

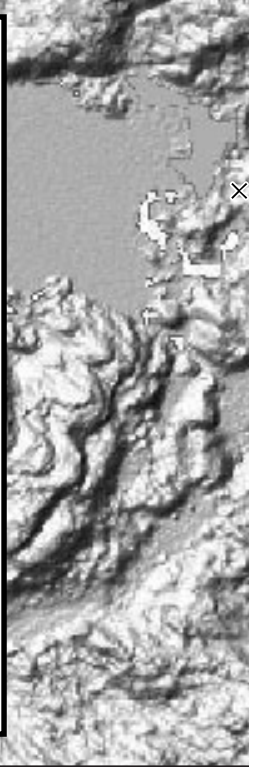




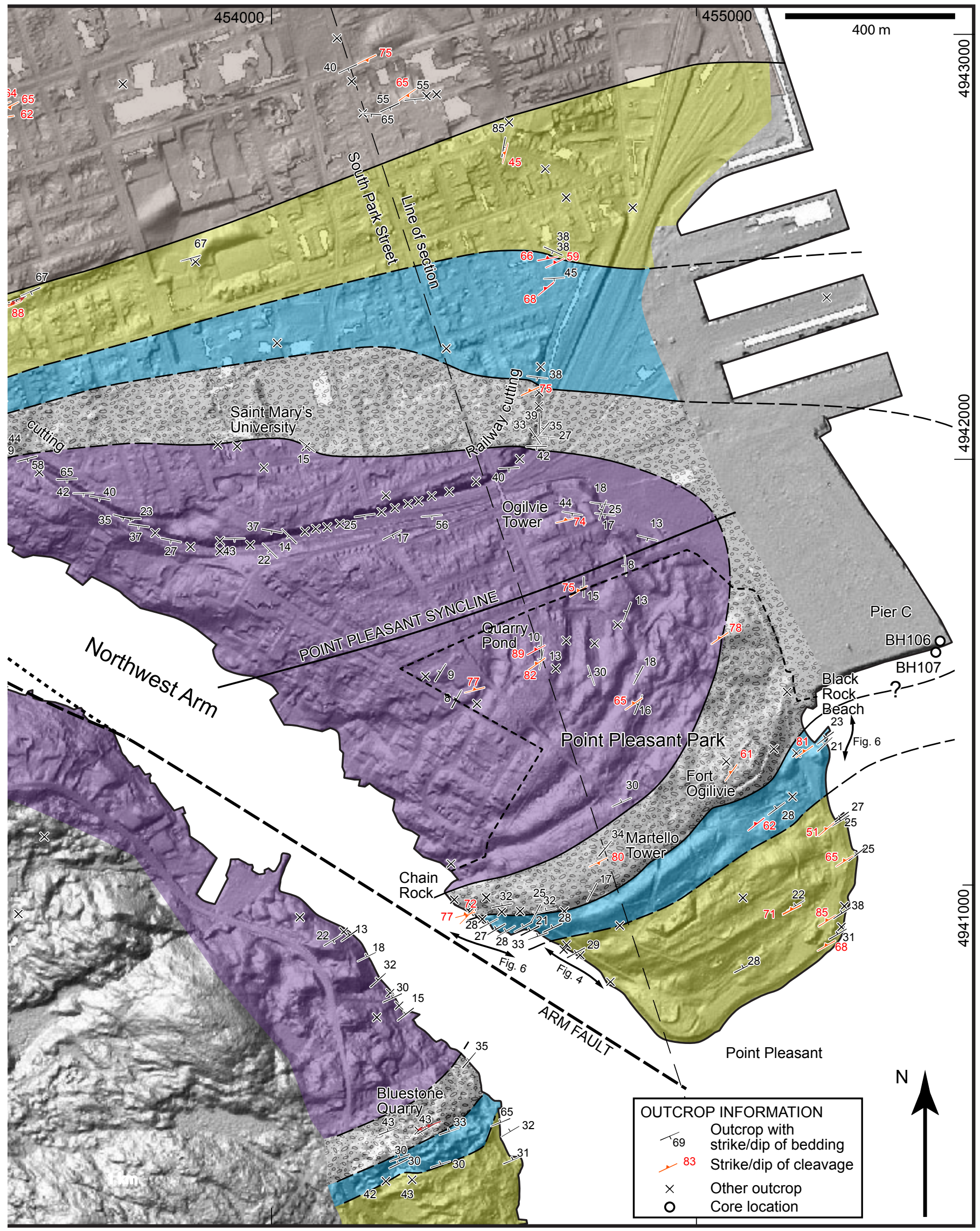


impossible. The stratigraphic top of the member is not seen, and is poorly exposed in residential areas of the Halifax "south end". The only younger units exposed are poorly lithified Quaternary deposits that overlie all the members with an angular unconformity. The preserved portion of the Quarry Pond member on Halifax Peninsula is estimated at $\sim 200 \mathrm{~m}$ thick. Its likely equivalent is present in the core of the Point Pleasant syncline in the Williams Lake area west of the Northwest Arm; further mapping in this area would be required to determine whether higher stratigraphy is present in the aureole of the South Mountain Batholith.

\section{MAP-SCALE STRUCTURE OF HALIFAX PENINSULA}

\section{Map-scale folds}

Basic elements of the structure were established by Faribault (1908). Most outcrops show steeply dipping strata and the overall succession youngs to the SSE. However, the Peninsula contains several upright map-scale folds that produce local north-younging sections. A strong cleavage, axial planar to these folds, is present, but towards the SW becomes progressively annealed by the contact metamorphic overprint of the Halifax Pluton, part of the Devonian South Mountain Batholith that occupies the area west of the Halifax Peninsula. Metamorphic reactions and isograds related to this intrusion were documented by Jamieson et al. (2012).

For this study, outcrop locations in the southern part of the Peninsula, including some temporary outcrops opened during construction projects, were located and described, and plotted on a hill-shaded LiDAR image using ArcGIS (Fig. 8). A single large fold, the Point Pleasant syncline, is present in the area of detailed mapping. Topographic lineaments visible in the LiDAR image helped in the interpolation of unit boundaries between outcrops. The data were interpreted and projected down the plunge of the fold to create the vertical cross-section shown in Figure 8a.

Poles to bedding (Fig. 9) lie in a well-defined girdle distribution about an axis plunging gently WSW, indicating a well behaved cylindrical fold. To build the cross-section (Fig. 8a), locations were axially projected onto a vertical plane transverse to the fold trend. (This is almost coincident with one set of main street orientations. The constructed cross-section, passing through a Martello Tower in Point Pleasant Park, runs approximately along Young Avenue and South Park Street.) Bedding and cleavage orientations were projected onto the plane of cross-section and are shown as apparent-dip "tadpoles". Estimates of the thicknesses of the stratigraphic units can be obtained from the section, but because of the gentle plunge the geometry and thickness of layers at depth are less well constrained than those close to the surface. In estimating the position of contacts at depth we have assumed a similar-fold geometry (class 2 of Ramsay 1967).

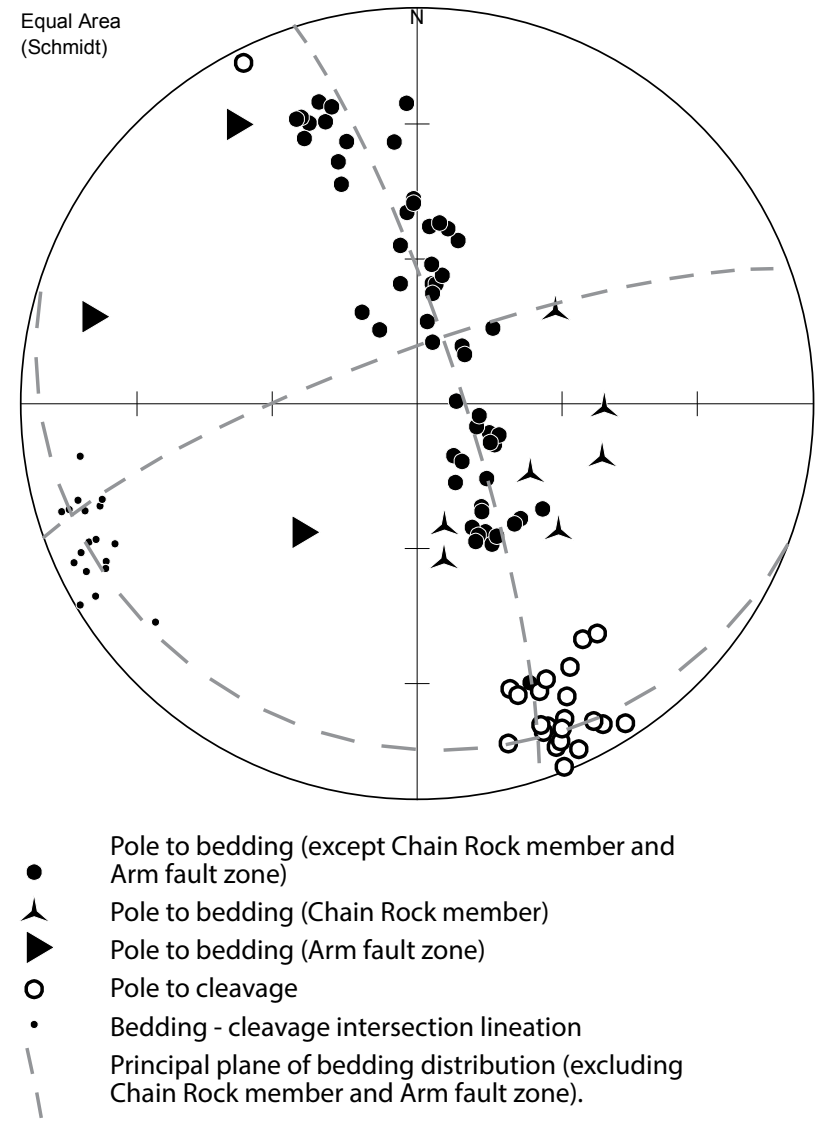

Figure 9. Equal-area lower-hemisphere projections of structures in southern Halifax Peninsula and adjacent areas.

A small number of bedding poles (shown by distinct symbols in Fig. 9) lie outside the main girdle distribution. These measurements are from two areas. Bedding at some outcrops adjacent to Northwest Arm (Fig. 8) is rotated counterclockwise relative to the rest of the peninsula, consistent with the presence of a sinistral fault along Northwest Arm (see below). In addition, bedding measurements from the Chain Rock member of the Bluestone Quarry Formation fall outside the main girdle distribution, suggesting a more complex structural history, here interpreted to involve deformation that took place before lithification.

\section{Cleavage}

Poles to cleavage (Fig. 9) are tightly clustered, and are oriented approximately parallel to the axial surface, or hinge surface, of the Point Pleasant syncline. A well-developed intersection lineation plunges gently WSW, though its mean orientation is very slightly $\left(3^{\circ}\right)$ counterclockwise of the fold axis determined from bedding orientations, consistent with a component of dextral strike-slip shear during fold tightening.

Cleavage and the map-scale folding overprint outcropscale deformation features that are restricted to the Chain Rock member, described in the following sections, and 
here interpreted as synsedimentary. These features include conspicuous variations in the orientation of the intersection lineation, rootless folds that are cross-cut by cleavage, and boudinage and fragmentation of siltstone layers, all absent in the overlying and underlying members.

\section{Later structures}

Structures associated with folding and cleavage development are overprinted by the contact aureole of the Halifax Pluton, one of the constituent intrusions of the South Mountain Batholith. Distinct dextral shear zones, with offsets of a few metres, striking $\sim 235^{\circ}$ approximately parallel to regional cleavage, are visible at the Martello Tower location. They are possibly attributable to reactivation of the cleavage planes during Carboniferous strike slip. NW-striking faults (Fig. 2) are postulated beneath Halifax Harbour (Mill Cove Fault) and along Northwest Arm (Arm Fault) by White et al. (2008) and White and Goodwin (2011) These are parallel to a well developed family of sinistral faults on the Nova Scotia Eastern Shore (Fig. 1) mapped by Henderson et al. (1986). Our mapping indicates 200-300 m of sinistral separation of members of the Bluestone Quarry Formation where they dip NW on the south limb of the Point Pleasant syncline. The true slip cannot be precisely determined because of poor exposure in the northwest of the area mapped in Figure 8, but map relationships suggest smaller offsets of SE-dipping contacts, consistent with an oblique-slip combination of $\sim 170 \mathrm{~m}$ sinistral strike slip and $\sim 100 \mathrm{~m}$ west-side-down dip slip. White et al. (2008) traced the Arm Fault north to Bedford Basin, where they record dextral separation; one possibility shown in Figure 2 is that the Arm Fault branches at the head of Northwest Arm, and that the dextral separation documented by White et al. represents a conjugate fault with more northerly strike. The timing of movement on the Arm Fault is also unknown, but the orientation and slip would be consistent with a conjugate relationship with Carboniferous dextral movement on the Minas Fault Zone that strikes east-west along the northern boundary of the Meguma terrane (Murphy et al. 2011).

\section{FEATURES OF THE CHAIN ROCK MEMBER: A SEDIMENTARY MASS-TRANSPORT DEPOSIT}

\section{Lower contact relations}

At Chain Rock on the $\mathrm{W}$ side of Point Pleasant Park, the basal contact of the member (Fig. 10a) is sharp, and cross-cuts bedding in the underlying Black Rock Beach member. Above the contact, the Chain Rock member shows only discontinuous and contorted beds and laminae. Although this contact appears to show a primary erosional relationship at the base of the member, it is marked by a distinct post-metamorphic fracture, and it is difficult to exclude the possibility that the basal contact of the member at this location was exploited by later brittle faulting.
However, both to the NE and to the SW, outcrops of the basal contact are annealed by metamorphism and unaffected by later fracturing (Fig 10b). In the area of Bluestone Quarry the basal contact is observed to be discordant, cutting down to the SW; small shear zones are present in the top $\sim 5 \mathrm{~m}$ of the underlying Black Rock Beach member. Intact beds present in the basal $\sim 10 \mathrm{~m}$ of the Chain Rock of the member are locally folded in asymmetric folds at the contact (Fig. 10d); because of the smooth outcrop surface, the orientation of these folds cannot be determined in three dimensions, but the observed geometry suggests a component of vergence to the NE. Above the contact, the basal $10 \mathrm{~m}$ of Chain Rock member contains rafts, up to $2 \mathrm{~m}$ long, of intact and partially disrupted beds (Fig. 7c).

To the NE of Chain Rock, the basal contact is not, to our knowledge, exposed elsewhere within the park, but it must pass between Black Rock Beach and a small unstratified outcrop of the Chain Rock member located beside the beach parking lot. The base is, however, exposed in the north limb of the Point Pleasant syncline, immediately west of a series of grain elevators that form a conspicuous feature of the Halifax waterfront. The contact is relatively structureless, between a graded sandstone bed below and disorganized MTD slate above (Fig. 10e). About $3 \mathrm{~m}$ above the contact, the Chain Rock member displays bedding that is deformed into a tight fold that produces strongly curved intersection lineations on the regional slaty cleavage, showing that the cleavage transects both limbs of the fold (Fig. 7e).

\section{Internal structure}

The interpreted internal structure of the Chain Rock member is shown in Figure 11. Immediately above the basal contact at Chain Rock no continuous beds are visible in the hornfels. However, scattered lenses of pale metasiltstone show a smaller proportion of cordierite porphyroblasts than their matrix, and contain visible laminae of pale metasiltstone that are folded in open to tight folds (Figs. $7 \mathrm{a}, \mathrm{b})$. Locally, deformed cross-lamination is visible in these disrupted inclusions of bedded metasedimentary rock. Jamieson et al. (2012) showed that some are rich in calc-silicates, and therefore that they represent originally carbonate-cemented material.

At Fort Ogilvie, a number of glacially and anthropogenically eroded surfaces are present. Clear graffiti from former military activities in the park display prominent dates that show the timing of the latest, anthropogenic erosion. However, they partially obscure the internal structures of the unit. No sampling is possible in this historic site. On close examination, no continuous bedding is visible anywhere within this group of outcrops. Instead, metasiltstone forms equant to moderately elongated ovoid lumps up to $15 \mathrm{~cm}$ in diameter, locally with disturbed internal lamination, immersed in dark pelite (Fig. 7d).

Other scattered outcrops of the member within Point Pleasant Park can be found on the scarp of the ridge that 

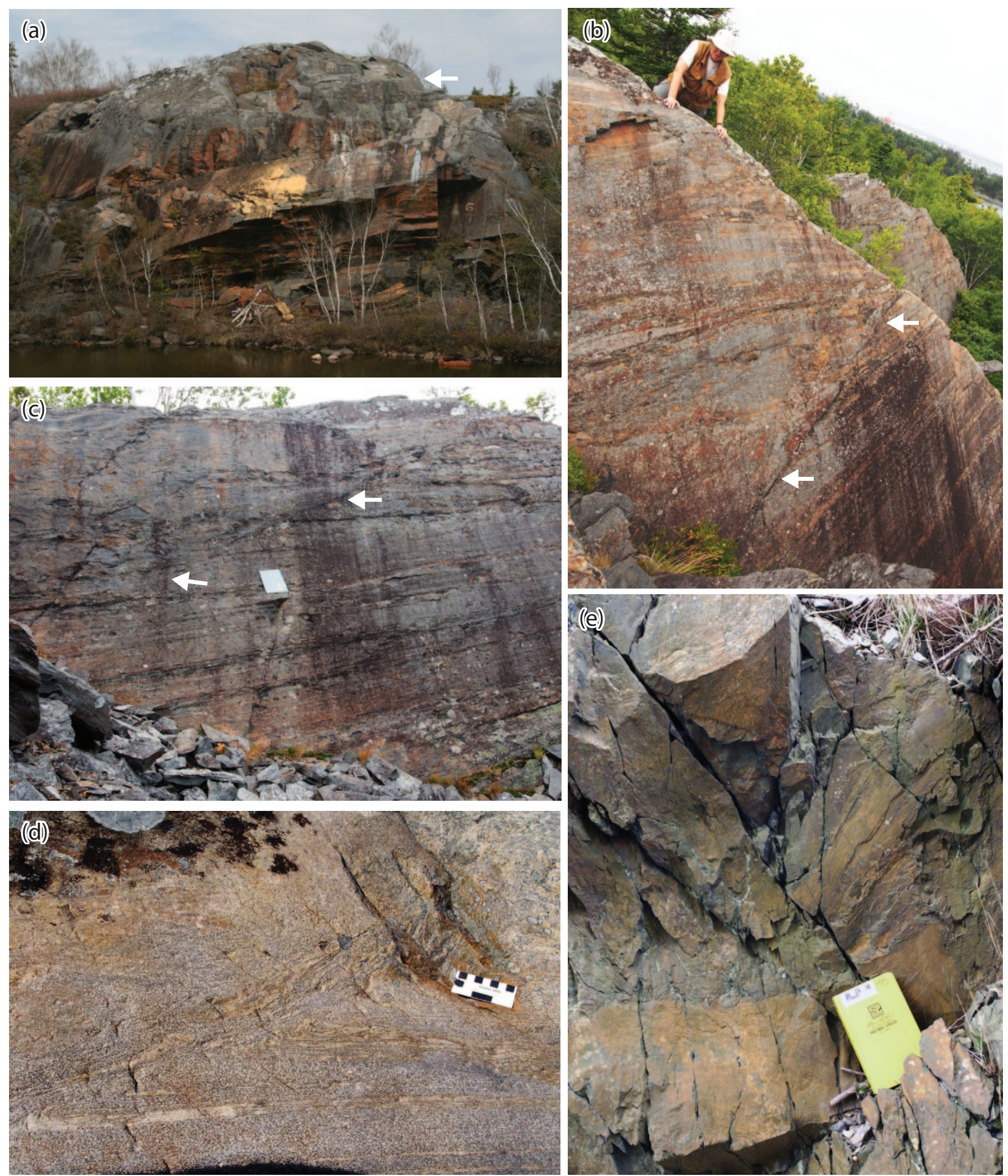

Figure 10. Field photographs of basal contact of Chain Rock member. (a) View of basal contact at Bluestone Quarry. Massive Chain Rock member overlies well bedded Black Rock Beach member. (b) Basal contact at Bluestone Quarry (arrows) cutting down-section to west (left) into underlying Black Rock Beach member. (c) Contact at Bluestone Quarry (arrows) immediately west of b, showing continued down-cutting to west (left). (d) Close-up of contact at Bluestone Quarry showing underlying folded strata in basal shear zone. (e) Basal contact in railway cutting shows mudstone with homogeneous fragmental texture resting on sandstone bed (contact is immediately above notebook). 
runs from Fort Ogilvie to Chain Rock (Fig. 8), where they typically show strong cleavage but no continuous bedding. Where bedding is present, it is typically disrupted and locally folded. Approximately $200 \mathrm{~m}$ east of Chain Rock, folds within the unit plunge east and face downward, indicating that they pre-date the cleavage-related folding associated with the Point Pleasant syncline. On the north limb of the Point Pleasant syncline, outcrops in both intersections of the railway cutting show similar characteristics (Fig. 7f).

\section{Upper contact relations}

The top of the member is not visible on the coast at Chain Rock, but $\sim 400 \mathrm{~m}$ to the east, at the Martello Tower (Fig. 8), an extensive glacially polished surface shows folded beds and laminae interpreted to mark the upper part of the Chain Rock member. Beds are offset by several small late shear zones striking WSW. However, between these, bedding is notably more continuous than at Chain Rock, but contrasts with other locations in the park in showing outcrop-scale folds (e.g., Figs. 12a, b). Although measurement in 3D is difficult because of the smooth outcrop surface, and sampling is not possible because of the historic nature of the site, the folds clearly trend dominantly NE-SW, roughly

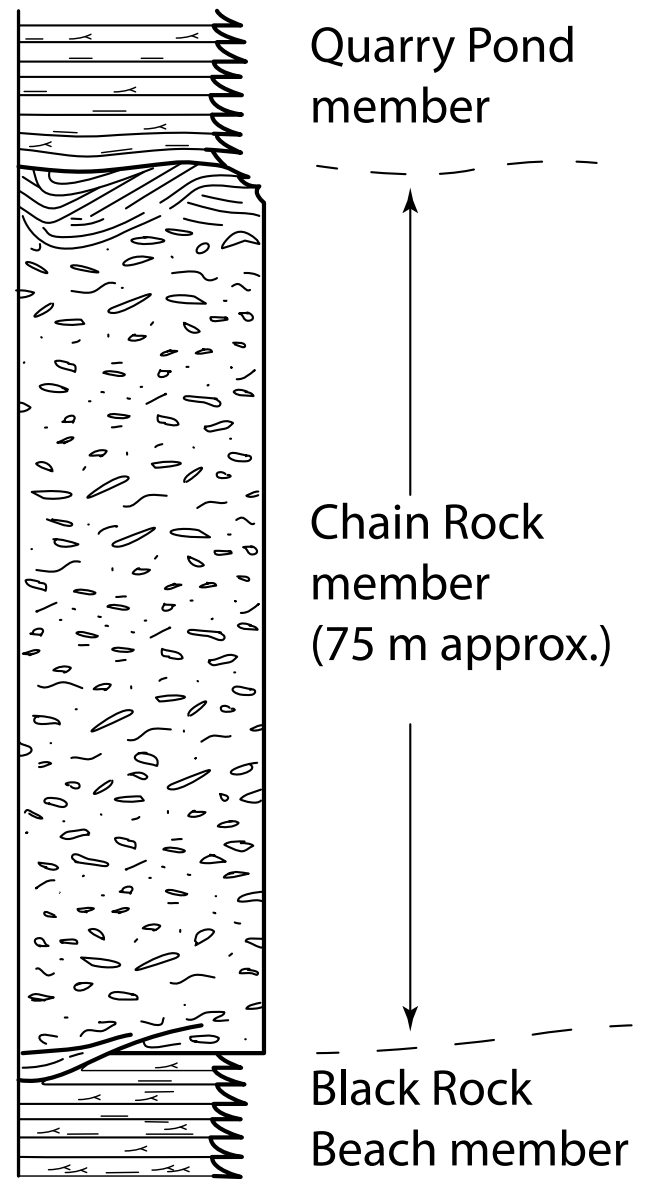

Figure 11. Schematic vertical section of Chain Rock member, compiled from observations at diverse locations within the unit. parallel to the regional strike of cleavage and the trend of the map-scale Point Pleasant Syncline. However, the plunges of the folds vary from gently NE to gently SW, and a number of folds must be doubly-plunging, with curved hinges, in contrast to the highly cylindrical character of the mapscale tectonic folds. At one point on the erosion surface (Fig. 12a), both limbs of a folded bed are truncated at the base of an overlying layer, suggesting that synsedimentary folding was followed by erosion, prior to deposition of the upper bed. The top of the member is drawn at the top of the highest disrupted or truncated bed, below parallel-bedded and laminated metapelites of the Quarry Pond member.

In the eastern railway cutting section, the top of the member is visible at a point (Fig. 12c) where coherent parallel-bedded metapelite of the Quarry Pond member overlies, with angular discordance, bedded but folded metapelite interpreted as the top of the Chain Rock member. About $5 \mathrm{~m}$ below the top, another interval of coherent bedding is concordant with the overlying Quarry Pond member, but lateral continuity of exposure is insufficient to determine whether this interval is a raft within a single disrupted layer or whether it is an undeformed section between two separate disrupted intervals.

Two glacially polished outcrops on the campus of Saint Mary's University appear to include the upper contact of the member. The Chain Rock member is represented by folded strata in the eastern outcrop while the western outcrop shows a boundary between homogeneous unbedded mudstone with small irregular and lenticular siltstone inclusions, overlain by bedded laminated siltstones and mudstones of the Quarry Pond member (Fig. 12d), locally ponded in the irregular upper surface of the Chain Rock member.

\section{DISCUSSION}

\section{Origin of the Chain Rock member}

Waldron and Gagnon (2011) have underscored the difficulty and controversy associated with the identification of soft-sediment deformation in the tectonically deformed rocks of orogens. Where cleavage is developed during tectonic deformation it can be difficult or impossible to determine whether pre-cleavage structures were developed in lithified or unlithified sediments. Even where deformation of unlithified sediments is suspected, it may be impossible to determine whether this deformation occurred as a result of down-slope gravitational sliding or deep-rooted tectonic deformation. In this section we review the evidence that suggests that the sediments of the Chain Rock member underwent deformation while only partially lithified, and discuss the environment in which that deformation occurred.

A number of features of the Chain Rock member (Fig. 11) indicate that it has undergone a more complex deformation history than other parts of the Bluestone Quarry Formation. 

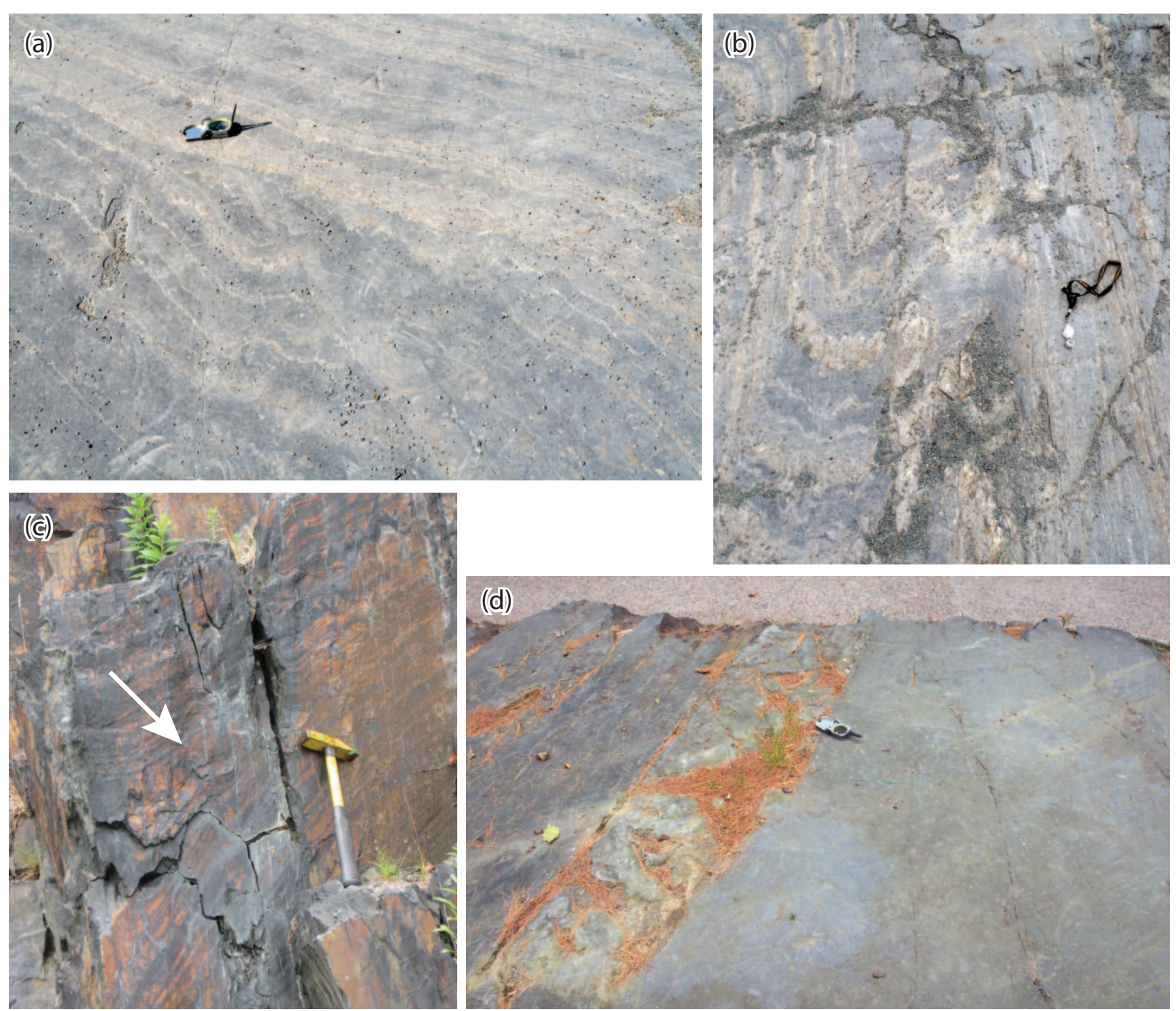

Figure 12. Relationships at top of Chain Rock member. (a) Glacially polished outcrop at Martello Tower, showing possible sedimentary truncation of folded strata, immediately below compass. (b) Glacially polished outcrop at Martello Tower, showing upright folds with axial traces parallel to regional cleavage. (c) Railway cutting, showing truncation of tilted strata by lowest beds of Quarry Pond member (arrow). (d) Irregular upper surface of Chain Rock member (beneath compass) locally overlain by a $\sim 30 \mathrm{~cm}$ bed of sandstone, marking the base of the Quarry Pond member, south entrance to Sobey Building, Saint Mary's University campus. Stratigraphic top is to left.

These features include fragmented bedding, folds with varied orientations including examples that face downward, and bedding-cleavage intersections that are not parallel to regional fold trends. Cleavage itself is not visibly affected by these structures, and is consistent in orientation with other parts of the Bluestone Quarry Formation, indicating that the additional deformation features developed before regional Neoacadian deformation.

The style of folds, and the presence of coarse blocks and boudins immersed in a fine-grained matrix, indicate major ductility contrasts during deformation of the Chain Rock member. Such ductility contrasts may occur both in sediments that are wet and in metasedimentary rocks that are close to their melting point. A high-temperature origin for deformation structures can be excluded, even in the case of thermally metamorphosed rocks in the contact aureole of the Halifax Pluton, because thermal metamorphism in the aureole overprints cleavage, and therefore post-dates the regional deformation event; in contrast the deformation features characteristic of the Chain Rock member clearly pre-date this cleavage. Deformation of incompletely lithified sediment is thus the most reasonable interpretation for the distinctive structures seen in the Chain Rock member.

However, the Chain Rock member clearly incorporated blocks that were preferentially cemented with carbonate, now preserved as calc-silicate minerals (Jamieson et al. 2012). Mineralogically, these resemble carbonate concretions found in the bedded members of the Bluestone 
Quarry Formation (e.g., Fig. 3a). Carbonate concretions can form very early in diagenetic history, prior to lithification of surrounding sediment. Gagnon and Waldron (2011) described concretions incorporated in a large MTD in the Jurassic Bowser Lake Group of British Columbia at Divide Lake (Fig. 13), a unit that provides a striking unmetamorphosed analogue for the Bluestone Quarry Formation.

Further support for a pre-lithification origin can be drawn from the stratabound nature of the deformation, which is confined to the Chain Rock member, and from observations at the upper contact, particularly at the Martello Tower location (Fig. 12a), which are consistent with an angular unconformable relationship between lithologically similar strata above and below the contact.

These relationships indicate both that the Chain Rock member originated by deformation of unconsolidated sediment, and that the deformed materials were exposed at the sediment-water interface, where they were covered unconformably by the Quarry Pond member.

Deformation of unconsolidated sediments is most commonly attributed to downslope gravity sliding. However, Waldron and Gagnon (2011) pointed out that tectonic processes deform wet sediments in present-day settings such as subduction zones, and can be expected to have done so in the past; distinguishing between downslope and deep-rooted deformation of wet sediments can be challenging. In the case of the Chain Rock member, there is no evidence that the member connects to a deep-rooted thrust fault, nor that adjacent stratigraphy is duplicated by thrusting. The Chain Rock member does not contain fragments exotic to the Bluestone Quarry Formation, and there is no evidence for major Tremadocian tectonism in the Meguma terrane, although 'Penobscot' and 'Monian' deformation occurs at this time in other terranes of the Appalachian-Caledonide orogen (Neuman and Max 1989). Thus we infer that pre-lithification deformation in the Chain Rock member occurred primarily by down-slope gravitational sliding. However, movement may have been triggered by tectonic instability elsewhere in the periGondwanan domain, via increased sedimentation rates and/or seismic shaking.

\section{Development of the mass-transport deposit}

The folds at the base of the Chain Rock member probably formed at the base of the transported material, in response to traction exerted by gravity and by the moving material above. The direction of sliding is poorly constrained. Inferences of transport direction from the symmetry and facing directions of folds are limited by the glacially smoothed nature of many outcrops, and by the possibility that rootless folds may have undergone rotation within the flow. Strachan and Alsop (2006) have emphasized the challenges in inferring transport direction from fold data. The few examples available in the Chain Rock member (Figs. 7e, 11d) are consistent with transport generally towards the north, compatible with the limited evidence
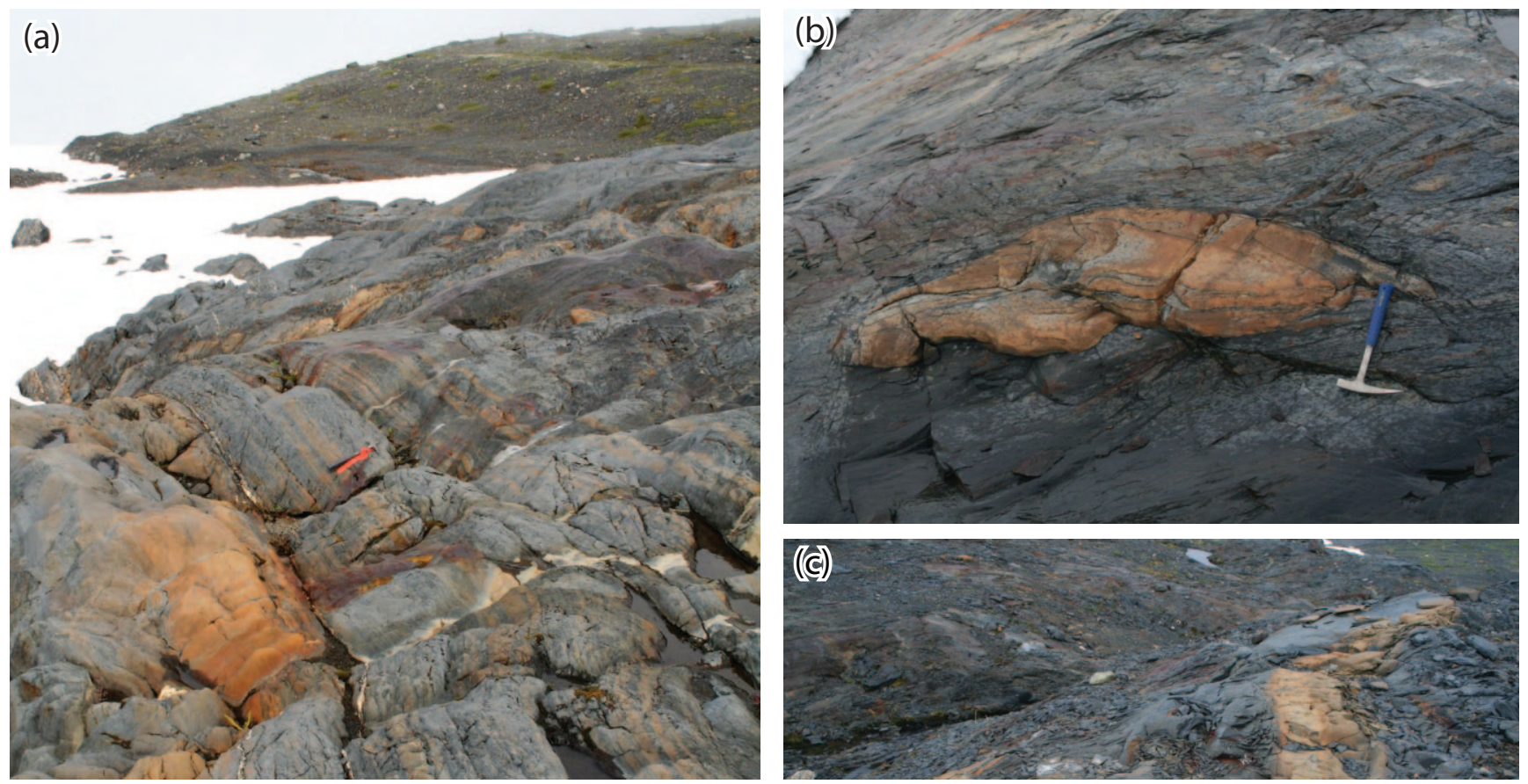

Figure 13. Mass-transport deposit in Jurassic Bowser Lake Group, Divide Lake, British Columbia, showing deformed orange carbonate-cemented raft immersed in black shale matrix, a possible unmetamorphosed analogue for the Chain Rock member. (a) General view showing bedded sedimentary rocks (centre, left) overlain by MTD (distance, right). (b and c) Close-ups of deformed isolated blocks of carbonate-cemented material enclosed in dark pelitic matrix. 
of paleoflow inferred from sedimentary structures in the underlying members (Fig. 5) and in other parts of the Goldenville and Halifax groups (e.g., Waldron and Jensen 1985; Waldron 1988; Gingras et al. 2011). The greatest disruption is seen in lower and central parts of the flow, where most coarse-grained beds are reduced to equant isolated fragments. At the top of the member, tilted and folded laminated sediments are again seen, and bedding continuity is greater. Observations at the Martello Tower and in the railway cutting (Figs. 12a, c) indicate that the upper parts of the flow show less disruption and that lithologies and lamination style in the folded upper part of the Chain Rock member are otherwise very similar to the overlying Quarry Pond member. This suggests that the later stages of mass transport may have been intermittent, and that laminated and bedded sediments deposited on top of the initial MTD were folded and incorporated into the Chain Rock member by subsequent minor renewed slumping. The alternative explanation, that large rafts of stratified sediment were transported down-slope at the top of the MTD from a shallower source, is less attractive because of the close similarity in facies between the units above and below.

\section{Effect of superimposed tectonic deformation}

Some folds in the upper part of the Chain Rock member have axial surfaces close to those of the regional Neoacadian structures (e.g., Fig. 12b). They differ from the regional folds in having much smaller wavelength (metres as opposed to kilometres) and in showing curved hinges and variable hinge-line plunge. The similarity in orientation suggests that tightening of these folds may have occurred during tectonic deformation. Figure 14 suggests a mechanism whereby later tectonic deformation could preferentially cause folding in an earlier MTD. The diagram is drawn for an ideal flexural-slip fold; Horne et al. (2001) have shown that flexural slip was important in the tightening of folds in the Halifax Group. In flexural-slip folding, the plane of bedding undergoes neither extension nor shortening, and parasitic folds are unlikely to develop. However, bedding surfaces that have previously been rotated fall in either the shortening or the extension field of the strain ellipsoid, and are therefore more susceptible to folding and/or boudinage. The strata at the top of the Chain Rock member may thus have been more susceptible to folding than the overlying Quarry Pond member. Clearly this model is an oversimplification: the distortion of sedimentary structures in the coherent units of the Halifax Group shows that bedding surfaces underwent finite shortening during the Neoacadian folding, and therefore that flexural slip does not account for all the deformation. Nonetheless, this model may help to explain the abundance of folds in the MTD at localities like the Martello Tower (Fig. 12b).

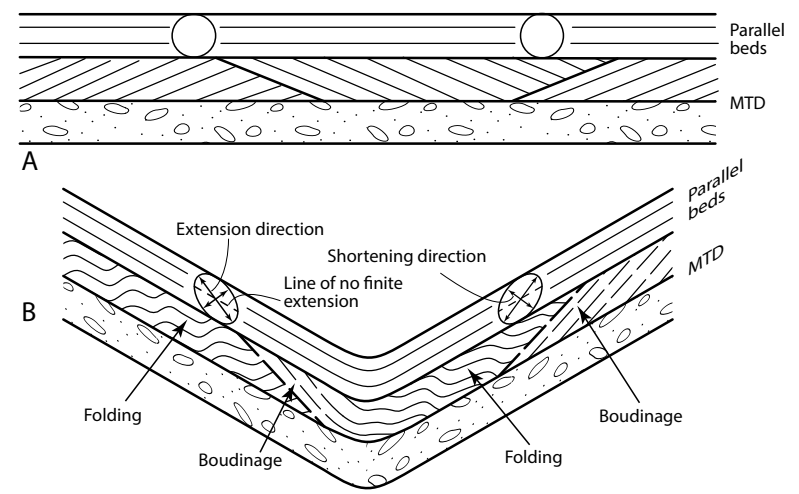

Figure 14. Simple kinematic model for flexural-slip folding of a previously deposited MTD consisting of large, variably oriented blocks. (a) Original configuration with two marker circles and beds reoriented by synsedimentary deformation at top of mass-transport deposit (MTD). (b) Configuration after folding. Marker circles are transformed into strain ellipses showing extension and shortening directions. Depending on their orientation, beds in MTD are subject to preferential shortening or extension leading to folding and boudinage respectively.

\section{Regional implications}

Most interpretations of the Goldenvilleand Halifax groups (Phinney 1961; Schenk 1970; Waldron and Jensen 1985) have favoured slope and submarine-fan environmental interpretations. MTDs are common in such environments and the lack of MTDs in previous interpretations is notable. Our observations in some of the most studied outcrops in Nova Scotia show how easily MTDs can be overlooked, and suggest that other undiscovered examples may exist elsewhere in the Meguma terrane.

The uppermost parts of the Halifax Group show less clear evidence of deepwater conditions. In the Wolfville area, White et al. (2012) have described the Elderkin Brook and Hellgate Falls formations that lack turbidite sedimentary structures and show an abundance of bioturbation, suggesting shelf environments. In southwest Nova Scotia, the Feltzen Formation (O’Brien 1986), contains deep U-shaped spreiten that are also more characteristic of shallow marine conditions. The Feltzen Formation is believed to be laterally equivalent to the Bluestone Quarry Formation, leading to the possibility that the rippled siltstones of the latter record shallowing. Figure 15 presents a simple stratigraphic model for the Halifax Group. Following a major transgression at the top of the Goldenville Group (Waldron 1992), recorded in the Beaverbank Formation and its correlatives, the overlying Halifax Group records deposition in a prograding regressive sequence where sediment supply exceeded accommodation, leading to overall shallowing. Our observations from the Bluestone Quarry Formation indicate deposition on a significant slope, and therefore show that shelf conditions had not yet been attained at the inferred Tremadocian time of deposition. 


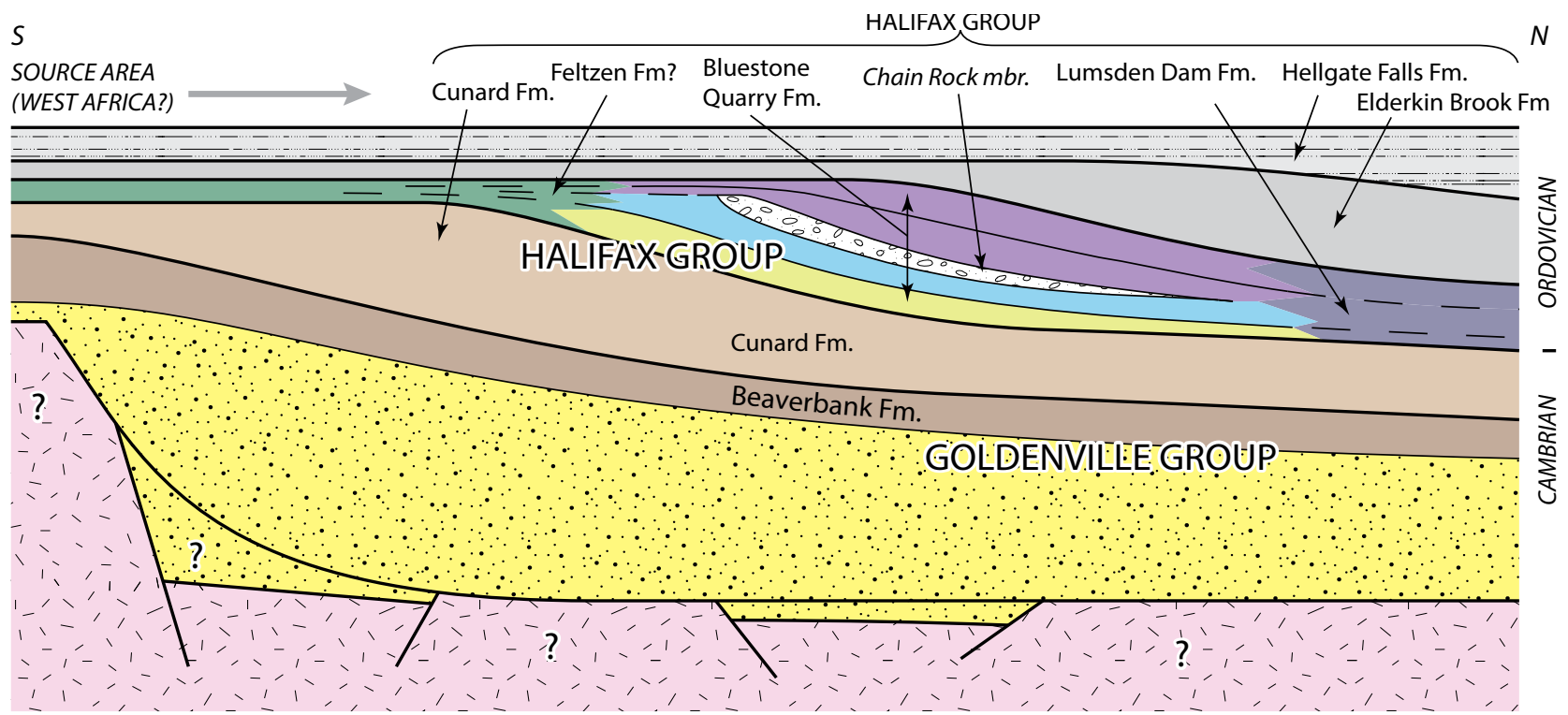

Figure 15. Inferred stratigraphic context of Bluestone Quarry Formation in a regressive sequence on a margin of Gondwana, modified from Waldron (1992). Stratigraphic nomenclature after White (2010) and White et al. (2012). Slope deposition of Chain Rock member is followed by slope progradation and a transition into shelf sediments represented by the Elderkin Brook and Hellgate Falls formations. Not to scale.

\section{CONCLUSIONS}

The Bluestone Quarry Formation in the Halifax area can be divided into four members. The lower, Point Pleasant member consists of thin to medium-bedded turbiditic metasiltstone and metasandstone interbedded with grey slate, and includes beds with complete Bouma sequences. The overlying Black Rock Beach member has thinner beds and is dominated by laminated and cross-laminated beds lacking the Bouma 'a' division.

The Chain Rock member is interpreted as a synsedimentary mass-transport deposit (MTD), produced by gravitational sliding on a submarine surface that sloped down generally to the $\mathrm{N}$ or NW. After initial movement, laminated sediment deposited on the top of the MTD was disrupted by additional pulses of downslope movement. The overlying Quarry Pond member is similar to the Black Rock Beach member.

All these units and structures are overprinted by regional Neoacadian folds and cleavage, and by the metamorphic aureole of the Halifax Pluton. The failure of several generations of geologists to identify the MTD, in some of the most visited outcrops in Nova Scotia, attests to the difficulty of recognizing synsedimentary deformation structures in successions that have subsequently undergone tectonic deformation (Waldron and Gagnon 2011).

\section{ACKNOWLEDGEMENTS}

We are grateful to Brian Fisher (NS Department of Natural Resources) for providing LiDAR and satellite base maps and we thank Nigel Woodcock and Mark Deptuck for helpful and useful reviews. We acknowledge the assistance Morgan Snyder, Neil Tobey, Glenn Hart, Luke Hilchie, and Glenn Chapman. This work was partially supported by NSERC Discovery Grants to JWFW and RAJ. CEW publishes with the permission of the Director of the Nova Scotia Department of Natural Resources. JWFW is grateful to Dalhousie University and Nova Scotia Department of Natural Resources for their hospitality during his sabbatical, and acknowledges discussions in the field with David Piper, Martin Gibling, Adam Fraser, Fergus Tweedale, and Grant Wach. RAJ acknowledges access to cores drilled by Stantec Ltd.

\section{REFERENCES}

Arnott, R.W.C., Wallace, K., and Laurin, J. 2011. Stratal architecture and temporal evolution of a passive margin mass-transport deposit, Neoproterozoic Isaac Formation, Cariboo Mountains, British Columbia, Canada. Special Publication - Society for Sedimentary Geology, 96, pp. 221-234.

Bouma, A.H. 1962. Sedimentology of some Flysch Deposits. A Graphic Approach to Facies Interpretation Elsevier, Amsterdam 168 p.

Clayton, C.J. 1993. Deflection versus reflection of sediment gravity flows in the late Llandovery Rhuddnant Grits turbidite system, Welsh Basin. 1993, 150, pp. 819-822.

Culshaw, N. and Liesa, M. 1997. Alleghenian reactivation of the Acadian fold belt, Meguma zone, southwest Nova Scotia. Canadian Journal of Earth Sciences, 34, pp. 833847. http://dx.doi.org/10.1139/e17-068 
Culshaw, N.G. and Reynolds, P. 1997. ${ }^{40} \mathrm{Ar} /{ }^{39} \mathrm{Ar}$ age of shear zones in the southwest Meguma Zone between Yarmouth and Meteghan, Nova Scotia. Canadian Journal of Earth Sciences, 34, pp. 848-853. http://dx.doi.org/10.1139/ e17-069

Debacker, T.N., Sintubin, M., and Verniers, J. 2001. Largescale slumping deduced from structural and sedimentary features in the Lower Palaeozoic Anglo-Brabant fold belt, Belgium. Journal of the Geological Society, 158, pp. 341-352. http://dx.doi.org/10.1144/jgs.158.2.341

Ducassou, E., Migeon, S., Capotondi, L., and Mascle, J. 2013. Run-out distance and erosion of debris-flows in the Nile deep-sea fan system: Evidence from lithofacies and micropalaeontological analyses. Marine and Petroleum Geology, 39, pp. 102-123. http://dx.doi.org/10.1016/j. marpetgeo.2012.09.006

Faribault, E.R. 1908. City of Halifax Sheet 68. Geological Survey of Canada Map 1019, scale 1:63 360.

Gagnon, J.-F. and Waldron, J.W.F. 2011. Sedimentation styles and depositional processes in a Middle to Late Jurassic slope environment, Bowser Basin, Northwestern British Columbia, Canada. Marine and Petroleum Geology, 28, pp. 698-715. http://dx.doi.org/10.1016/j. marpetgeo.2010.06.004

Gingras, M., Waldron, J.W.F., White, C.E., and Barr, S.M. 2011. The evolutionary significance of a lowermost(?) Cambrian trace fossil assemblage from the Meguma terrane, Nova Scotia. Canadian Journal of Earth Sciences, 48, pp. 71-85. http://dx.doi.org/10.1139/E10-086

Henderson, J.R. 1986. Geology, Ecum Secum area, Nova Scotia. Geological Survey of Canada Map 1648A, scale 1:50,000.

Hibbard, J.P., van Staal, C.R., Rankin, D.W., and Williams, H. 2006.Lithotectonic map of the Appalachian orogen, Canada - United States of America: Geological Survey of Canada Map 02096A, scale 1:1 500000.

Horne, R. and Culshaw, N. 2001. Flexural-slip folding in the Meguma Group, Novas Scotia, Canada. Journal of Structural Geology, 23, pp. 1631-1652. http://dx.doi. org/10.1016/S0191-8141(01)00017-7

Jamieson, R.A., Tobey, N., and ERTH3020 2005. Contact metamorphism of the Halifax Formation on the southeastern margin of the Halifax Pluton, Halifax, Nova Scotia. GAC-MAC-CSPG-CSSS Joint Annual Meeting, Halifax, Nova Scotia, Abstracts, 30, p. 95.

Jamieson, R.A., Hart, G.G., Chapman, G.G., and Tobey, N.W. 2012. The contact aureole of the South Mountain Batholith in Halifax, Nova Scotia: geology, mineral assemblages, and isograds. Canadian Journal of Earth Sciences, 49, pp. 12801296. http://dx.doi.org/10.1139/e2012-058

Murphy, J.B., Waldron, J.W.F., Kontak, D., Pe-Piper, G., and Piper, D.J.W. 2011. Minas Fault Zone: Late Paleozoic history of an intra-continental orogenic transform fault in the Canadian Appalachians. Journal of Structural Geology, 33, pp. 312-328. http://dx.doi.org/10.1016/j. jsg.2010.11.012
Neuman, R.B. and Max, M.D. 1989. PenobscottianGrampian-Finnmarkian orogenies as indicators of terrane linkages. In Terranes in the circum-Atlantic orogens. Edited by R.D. Dallmeyer. Geological Society of America Special Paper, 230. pp. 31-45. http://dx.doi. org/10.1130/SPE230-p31

O'Brien, B.H. 1986. Preliminary report on the geology of the Mahone Bay area, Nova Scotia. In Current Research Part A. Geological Survey of Canada, Paper, 86-1A. pp. 439-444.

Phinney, W.C. 1961. Possible turbidity current deposit in Nova Scotia. Geological Society of America Bulletin, 72, pp. 1453-1454. http://dx.doi.org/10.1130/00167606(1961)72[1453:PTDINS]2.0.CO

Pothier, H.D., Waldron, J.W.F., DuFrane, S.A., White, C.E., and Jamieson, R.A. 2015. Stratigraphy, provenance and tectonic setting of the Upper Ordovician upper Halifax Group, Nova Scotia. Atlantic Geology, pp. 51-83.

Ramsay, J.G. 1967. Folding and Fracturing of Rocks McGraw Hill, San Francisco 568 p.

Reynolds, P.H., Kublick, E.E., and Muecke, G.K. 1973. Potassium- argon dating of slates from the Meguma Group, Nova Scotia. Canadian Journal of Earth Sciences, 10, pp. 1059-1067. http://dx.doi.org: 10.1139/e73-091

Schenk, P.E. 1970. Regional variation of the flysch-like Meguma Group (Lower Palaeozoic) of Nova Scotia, compared to recent sedimentation off the Scotian Shelf. In Flysch Sedimentology in North America. Edited by J. Lajoie. Geological Association of Canada Special Paper, 7, pp. 127-153.

Schwab, W.C., Lee, H.J., Twichell, D.C., Locat, J., Nelson, C.H., McArthur, W.G., and Kenyon, N.H. 1996. Sediment mass-flow processes on a depositional lobe, outer Mississippi Fan. Journal of Sedimentary Research, 66, pp. 916-927.

Stow, D.A.V., Alam, M., and Piper, D.J.W. 1984. Sedimentology of the Halifax Formation, Nova Scotia: Lower Palaeozoic fine-grained turbidites. In Fine Grained Sediments: Deep-Water Processes and Facies. Edited by D.A.V. Stow and D.J.W. Piper. Geological Society of London Special Publication, 15, pp. 127-144.

Strachan, L.J. and Alsop, G.I. 2006. Slump folds as estimators of palaeoslope: a case study from the Fisherstreet Slump of County Clare, Ireland. Basin Research, 18, pp.451-470. http://dx.doi.org/10.1111/j.1365-2117.2006.00302.x

Sumner, E.J., Talling, P.J., Amy, L.A., Wynn, R.B., Stevenson, C.J., and Frenz, M. 2012. Facies architecture of individual basin-plain turbidites: Comparison with existing models and implications for flow processes. Sedimentology, 59, pp. 1850-1887. http://dx.doi.org/10.1111/j.13653091.2012.01329.x

Sylvester, Z. and Lowe, D.R. 2004. Textural trends in turbidites and slurry beds from the Oligocene flysch of the East Carpathians, Romania. Sedimentology, 51, pp. 945-972. http://dx.doi.org/10.1111/j.13653091.2004.00653.x 
Waldron, J.W.F. 1988. Determination of finite strain in bedding surfaces using sedimentary structures and trace fossils: a comparison of techniques. Journal of Structural Geology, 10, pp. 273-281. http://dx.doi. org/10.1016/0191-8141(88)90060-0

Waldron, J.W.F. 1992. The Goldenville-Halifax transition, Mahone Bay, Nova Scotia: relative sea-level change in the Meguma source terrane. Canadian Journal of Earth Sciences, 29, pp. 1091-1105. http://dx.doi.org/10.1139/ e92-087

Waldron, J.W.F. and Jensen, L.R. 1985. Sedimentology of the Goldenville Formation, Eastern Shore, Nova Scotia. Geological Survey of Canada, Paper, 85-15, 31 p.

Waldron, J.W.F. and Gagnon, J.-F. 2011. Recognizing softsediment structures in deformed rocks of orogens. Journal of Structural Geology, 33, pp. 271-279. http:// dx.doi.org/10.1016/j.jsg.2010.06.015

White, C.E. and Goodwin, T.A. 2011. Lithogeochemistry, petrology, and the acid-generating potential of the Goldenville and Halifax groups and associated granitoid rocks in the metropolitan Halifax Regional Municipality, Nova Scotia, Canada. Atlantic Geology, 47, pp. 158-184. http://dx.doi.org/10.4138/atlgeol.2011.008
White, C.E. 2010. Stratigraphy of the Lower Paleozoic Goldenville and Halifax groups in southwestern Nova Scotia. Atlantic Geology, 46, pp. 136-154. http://dx.doi. org/10.4138/atlgeol.2010.008

White, C.E., Palacios, T., Jensen, S., and Barr, S.M. 2012. Cambrian-Ordovician acritarchs in the Meguma terrane, Nova Scotia, Canada: Resolution of early Paleozoic stratigraphy and implications for paleogeography. Geological Society of America Bulletin, 124, pp. 17731792. http://dx.doi.org/10.1130/B30638.1

White, C.E., Bell, J.A., McLeish, D.F., MacDonald, M.A., Goodwin, T.A., and Macneil, J.D. 2008. Geology of the Halifax Regional Municipality, Central Nova Scotia. In Mineral Resources Branch, Report of Activities 2007. Nova Scotia Department of Natural Resources, Report, ME 2008-1. pp. 125-139.

Editorial responsibility: Sandra M. Barr 